\title{
Hypertension Compendium
}

\section{Circulation Research Compendium on Hypertension}

The Epidemiology of Blood Pressure and Its Worldwide Management

Genetic and Molecular Aspects of Hypertension

Hypertension: Renin-Angiotensin-Aldosterone System Alterations

The Sympathetic Nervous System Alterations in Human Hypertension

Obesity-Induced Hypertension: Interaction of Neurohumoral and Renal Mechanisms

The Structural Factor of Hypertension: Large and Small Artery Alterations

Inflammation, Immunity, and Hypertensive End-Organ Damage

Clinical Value of Ambulatory Blood Pressure: Evidence and Limits

Sodium Intake and Cardiovascular Health

Randomized Controlled Trials of Blood Pressure Lowering in Hypertension: A Critical Reappraisal

New Approaches in the Treatment of Hypertension

Giuseppe Mancia, Guest Editor

\section{Hypertension}

\section{Renin-Angiotensin-Aldosterone System Alterations}

Luuk te Riet, Joep H.M. van Esch, Anton J.M. Roks, Anton H. van den Meiracker, A.H. Jan Danser

Abstract: Blockers of the renin-angiotensin-aldosterone system (RAAS), that is, renin inhibitors, angiotensin (Ang)-converting enzyme (ACE) inhibitors, Ang II type 1 receptor antagonists, and mineralocorticoid receptor antagonists, are a cornerstone in the treatment of hypertension. How exactly they exert their effect, in particular in patients with low circulating RAAS activity, also taking into consideration the so-called Ang II/aldosterone escape that often occurs after initial blockade, is still incompletely understood. Multiple studies have tried to find parameters that predict the response to RAAS blockade, allowing a personalized treatment approach. Consequently, the question should now be answered on what basis (eg, sex, ethnicity, age, salt intake, baseline renin, ACE or aldosterone, and genetic variance) a RAAS blocker can be chosen to treat an individual patient. Are all blockers equal? Does optimal blockade imply maximum RAAS blockade, for example, by combining 22 RAAS blockers or by simply increasing the dose of 1 blocker? Exciting recent investigations reveal a range of unanticipated extrarenal effects of aldosterone, as well as a detailed insight in the genetic causes of primary aldosteronism, and mineralocorticoid receptor blockers have now become an important treatment option for resistant hypertension. Finally, apart from the deleterious ACE-Ang II-Ang II type 1 receptor arm, animal studies support the existence of protective aminopeptidase A-Ang III-Ang II type 2 receptor and ACE2-Ang-(1 to 7)Mas receptor arms, paving the way for multiple new treatment options. This review provides an update about all these aspects, critically discussing the many controversies and allowing the reader to obtain a full understanding of what we currently know about RAAS alterations in hypertension. (Circ Res. 2015;116:960-975. DOI: 10.1161/CIRCRESAHA.116.303587.)

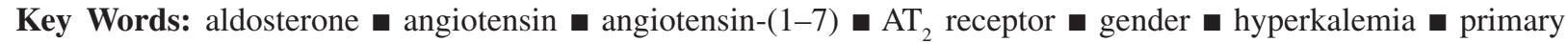

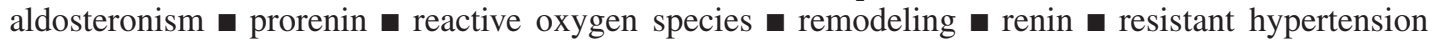

$\mathrm{B}$

lockers of the renin-angiotensin-aldosterone system

(RAAS), that is, renin inhibitors, ACE inhibitors, angiotensin (Ang) II type $1\left(\mathrm{AT}_{1}\right)$ receptor antagonists, and mineralocorticoid receptor (MR) antagonists, are a cornerstone in the treatment of hypertension. At first sight, their mechanism of action seems simple: they reduce the

Original Received June 4, 2014; revision received August 13, 2014; accepted August 13, 2014. In January 2015, the average time from submission to first decision for all original research papers submitted to Circulation Research was 14.7 days.

From the Division of Pharmacology and Vascular Medicine, Department of Internal Medicine, Erasmus MC, Rotterdam, The Netherlands.

Correspondence to A.H.J. Danser, PhD, Division of Pharmacology and Vascular Medicine, Department of Internal Medicine, Erasmus MC, Room EE1418b, Wytemaweg 80,3015 CN Rotterdam, The Netherlands. E-mail a.danser@erasmusmc.nl

(C) 2015 American Heart Association, Inc.

Circulation Research is available at http://circres.ahajournals.org

DOI: 10.1161/CIRCRESAHA.116.303587 


\begin{tabular}{|ll|}
\hline Nonstandard Abbreviations and Acronyms \\
\hline APA & aldosterone-producing adenoma \\
ARR & aldosterone-to-renin ratio \\
AT $_{1}$ & angiotensin Il type 1 \\
AT $_{2}$ & angiotensin II type 2 \\
BP & blood pressure \\
EC & endothelial cell \\
FH & familial hyperaldosteronism \\
GPER & G-protein-coupled estrogen receptor-1 \\
KO & knockout \\
MR & mineralocorticoid receptor \\
NO & nitric oxide \\
PA & primary aldosteronism \\
(P)RR & (pro)renin receptor \\
RAAS & renin-angiotensin-aldosterone system \\
SHR & spontaneously hypertensive rat \\
VSMC & vascular smooth muscle cell \\
\hline
\end{tabular}

formation or block the effects of Ang II and aldosterone, thereby preventing the deleterious cardiovascular effects of these 2 compounds. Logically, they should then be particularly applied in patients with high RAAS activity, as measured in blood plasma. However, it is now well accepted that they are also effective in patients with medium-tolow RAAS activity. Moreover, after an initial suppression/ blockade of Ang II/aldosterone, the plasma levels of these 2 compounds often return to normal or even rise above pretreatment levels: the so-called Ang II/aldosterone escape. ${ }^{1,2}$ Yet, remarkably, the RAAS blocker effect remains, at least partially. These puzzling observations have led to the concept of a local RAAS in various organs, that is, the real site of action of RAAS blockers. According to some investigators, this local RAAS occurs entirely intracellular (intracrine RAAS). ${ }^{3}$ In addition, during RAAS blocker application, an upregulation occurs of multiple angiotensin metabolites, which may exert actions of their own and possibly even contribute to the beneficial effects of RAAS blockade. Examples of these protective (vasodilator) pathways include the angiotensinase A-Ang III-Ang II type 2 $\left(\mathrm{AT}_{2}\right)$ receptor pathway and the ACE2-Ang-(1-7)-Mas receptor pathway (Figure 1). Further knowledge in this area might lead to new drugs.

For a long time, it was thought that the more RAAS blockade, the better, also in view of the above described Ang II/ aldosterone escape. However, dual RAAS blockade trials have now shown that this is not necessarily the case and that the consequences of too much RAAS suppression (hyperkalemia, renal dysfunction, and hypotension) may overrule the beneficial effects of this approach. A variety of RAAS differences exists between men and women, and between black and white people, with men and white people generally having higher renin levels. This does not necessarily translate into similarly elevated aldosterone levels, and in fact, patients with high aldosterone-to-renin ratios (ARR) can be identified, which respond particularly well to MR blockers. A wide range of mutations has recently been identified that gives rise to selective aldosterone rises.

This review will critically discuss all the above aspects. What is a local RAAS? What are the local actions of Ang II in the vessel wall? What are the (genetic) determinants of a solid response to a RAAS blocker? Is there such a thing as too much RAAS blockade? Are all RAAS blockers equally good? Are the sex- and ethnicity-related RAAS differences clinically relevant? What about the recent developments in primary hyperaldosteronism and the extrarenal effects of aldosterone? Finally, can we expect new RAAS drugs?

\section{What Is a Local RAAS?}

Originally, when developing the concept of local RAAS, it was proposed that all components required to generate Ang II, and aldosterone locally are synthesized at multiple sites in the body, allowing their generation to occur independently from the classical sites of RAAS component synthesis: the kidney (renin), liver (angiotensinogen), and adrenal (aldosterone). In addition, a wide variety of nonclassical enzymes, in particular chymase, was suggested to contribute to Ang II generation as well. ${ }^{4}$ Some, if not all, RAAS components were even detected in cells, leading to the concept of an intracrine RAAS, involving the intracellular generation of Ang II acting on intracellular (nuclear) receptors. ${ }^{3}$

Finally, the confusing observation that humans have large amounts of prorenin, the inactive precursor of renin, has led to a search for prorenin receptors that bind and activate prorenin locally, thus offering an explanation of why we have so much prorenin (its concentrations are $\leq 100$ times of renin): it would then function as a regulator of tissue Ang generation. One such candidate, the so-called (pro)renin receptor ((P)RR), which binds both renin and prorenin, has received much attention during the last decade. ${ }^{5}$ Unfortunately, the concentrations of renin/prorenin (together denoted here as (pro)renin) that are required to result in receptor binding are far above the normal (patho)physiological levels, and transgenic rodents overexpressing either the (P)RR or prorenin did not reveal any evidence for (pro)renin-(P)RR interaction in vivo, that is, their Ang II levels were unaltered. ${ }^{6}$ Moreover, (P)RR knockout $(\mathrm{KO})$, unlike renin $\mathrm{KO}$, is lethal. ${ }^{7}$ This may relate to $(\mathrm{P})$ RR's association with vacuolar $\mathrm{H}^{+}$-ATPAse, a crucial enzyme found in virtually every cell type that is important for the acidification of intracellular compartments. Therefore, (P)RR research is now focusing on its functions beyond the RAAS because the $(\mathrm{P}) \mathrm{RR}$ may not be a part of the RAAS after all, except perhaps in organs where (pro)renin is synthesized locally (allowing high local concentrations that result in receptor activation).

Similarly, the view of chymase as a major Ang I-II converting enzyme is most likely an in vitro artifact related to the measurement of Ang II formation in tissue homogenates (particularly from the human heart), where chymase is no longer in its intracellular storage sites. ${ }^{4}$ Careful measurements of Ang II in ACE KO mice did not support the concept that chymase is an Ang I-II converting enzyme in vivo. ${ }^{8}$ In fact, renin and angiotensin measurements are hampered by multiple technical difficulties, particularly in tissues, and because many of 


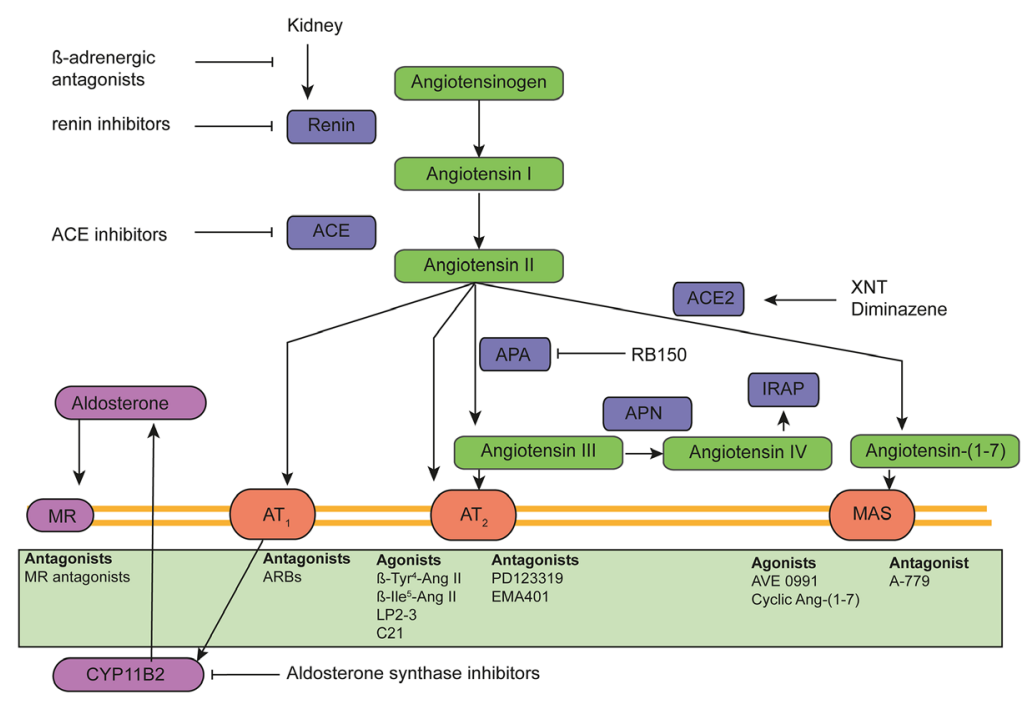

Figure 1. New and existing drugs interfering with the renin-angiotensin (Ang) system cascade. Classically, interference occurs at the level of renin, angiotensin-converting enzyme (ACE), the Ang II type $1\left(A T_{1}\right)$ receptor $(R)$, or the mineralocorticoid receptor (MR), with renin inhibitors, ACE inhibitors $A T_{1}$ receptor blockers (ARBs) or MR antagonists. Novel enzyme inhibitors now target aminopeptidase A (APA), which generates Ang III (=Ang-[2-8]) from Ang II (=Ang-1-8)), or aldosterone synthase (CYP11B2). Activators of ACE2 (XNT and diminazene), which generates Ang-(1-7) from Ang II, were recently found to act equally well in ACE2 knockout (KO) animals, thus questioning their mechanism of action. Numerous agonists for both the $\mathrm{AT}_{2}$ receptor and Mas receptor are being developed. Aminopeptidase N (APN) degrades Ang III to Ang IV (=Ang-(3-8)), which may act on the $\mathrm{AT}_{4}$ receptor, also known as insulin-regulated aminopeptidase (IRAP).

the original conclusions on tissue RAAS were based on such nonideal measurements, they need to be viewed with care. For instance, the original observations that renin and Ang II are unaltered after a bilateral nephrectomy turned out not to be true. ${ }^{9}$ Moreover, there is no intracellular Ang II in AT receptor KO mice. ${ }^{10}$ Clearly therefore, there is only one renin source in the body (the kidney), angiotensin generation occurs extracellularly (in blood, interstitial fluid, and on the cell surface), and any Ang II present in cells accumulated there after its internalization after AT receptor binding. Selective $\mathrm{KO}$ of renal angiotensinogen revealed that the concept of renal angiotensinogen contributing to renal Ang II production was not true: all renal Ang II generation depended on hepatic angiotensinogen. ${ }^{11}$ Although similar conclusions have been reached in the heart, ${ }^{12}$ local angiotensinogen synthesis has been claimed in the vessel wall, ${ }^{13}$ and adipocytes are generally believed to generate angiotensinogen. ${ }^{14}$ Surprisingly, adipocyte angiotensinogen deficiency did not affect plasma angiotensinogen levels, but greatly reduced circulating Ang II under high fat diet conditions. ${ }^{14}$ Additional studies, inducing selective $\mathrm{KO}$ of adipocyte angiotensinogen, hepatic angiotensinogen, or both are required to fully understand the contribution of adipocyte angiotensinogen to Ang II production. Also with regard to aldosterone, the original reports on its generation in heart, vessel wall, and kidney were not confirmed on careful re-examination of the measurements after adrenalectomy and in isolated organs. ${ }^{15-17}$

Summarizing, the current view is that Ang II generation in tissues does occur (in fact, $>90 \%$ of tissue Ang II is synthesized locally and not taken up from plasma ${ }^{18,19}$ ), but depends on renal renin and largely, if not completely, on hepatic angiotensinogen. Both diffuse into the interstitium, allowing local Ang II generation to take place in that compartment with the help of membranebound, ubiquitously present ACE (Figure 2). This Ang II rapidly binds to AT receptors, and such binding is followed by internalization, explaining why tissue Ang II levels are often high and correlate closely with tissue AT receptor density. ${ }^{20}$ Aldosterone is exclusively adrenal-derived. To what degree prorenin has a role, beyond the $(\mathrm{P}) \mathrm{RR}$, remains to be determined.

\section{Local Effects of Ang II in the Vessel Wall}

When focusing on the vessel wall, it is well-established that activation of $\mathrm{AT}_{1}$ receptors induces vasoconstriction, endothelial dysfunction, inflammation, growth, and remodeling, whereas $\mathrm{AT}_{2}$ receptors are believed to counteract these effects (Figure 3). However, the latter is not a uniform finding,

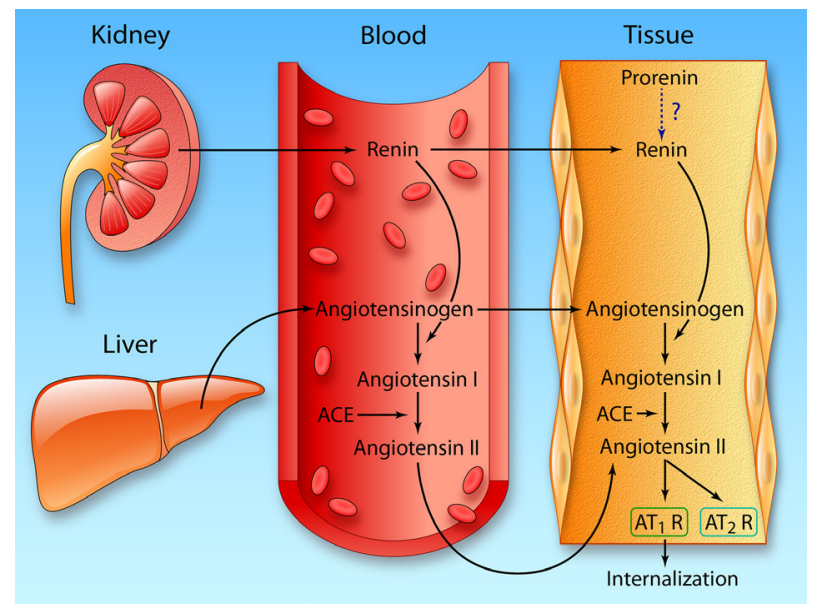

Figure 2. Circulating versus tissue renin-angiotensin (Ang) system. Circulating renin is kidney-derived, and circulating angiotensinogen originates in the liver. Angiotensin-converting enzyme (ACE) is located on endothelial cells. Ang II generated in the circulation will diffuse to tissues to bind to its main receptor (the Ang II type 1 receptor, $A T_{1} R$ ) to exert effects. In addition, circulating renin and angiotensinogen might also diffuse to tissue sites (eg, the interstitial space) and generate, with the help of tissue ACE, Ang II locally. In a limited number of tissues, renin's precursor prorenin is produced locally. To what degree such prorenin, for example, following its conversion to renin, contributes to local angiotensin production remains unknown. Although local production has also been claimed for angiotensinogen, in particular in the kidney, current evidence does not support a functional role for kidney-derived angiotensinogen because the renal Ang II levels in renal angiotensinogen knockout (KO) mice are identical to those in wild-type mice. ${ }^{11}$ Locally generated Ang II rapidly binds to $A T_{1}$ and $A T_{2}$ receptors, the former being followed by internalization. This explains the intracellular presence of Ang II, as well as the high tissue levels of Ang II in high AT, receptor-density organs like the adrenal (Illustrated Credit: Ben Smith). 


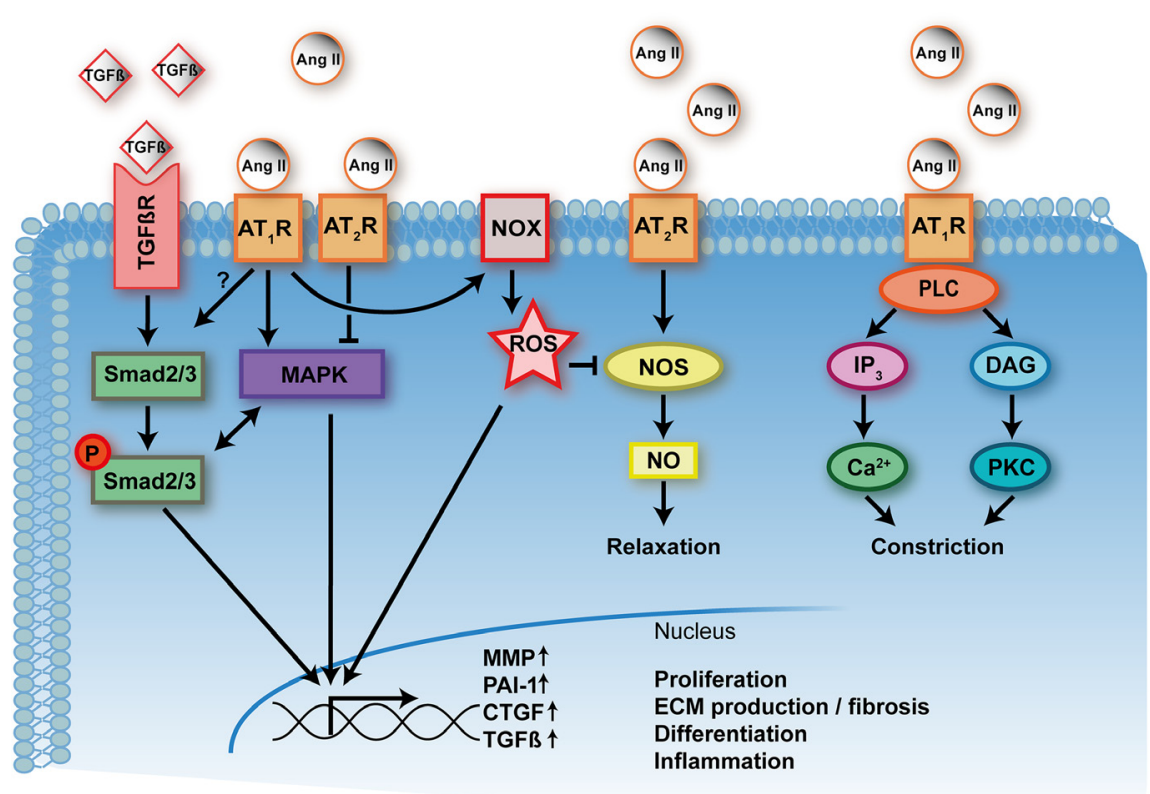

Figure 3. Effects of angiotensin (Ang) II, via its Ang II type 1 and 2 (AT ${ }_{1}$ and AT $_{2}$ ) receptors (AT $\mathrm{R}_{\text {, }} \mathrm{AT} \mathrm{T}_{2} \mathrm{R}$ ) on vascular remodeling and constriction/vasodilation. Transforming growth factor- $\beta$ (TGF- $\beta$ ) signaling by the TGF- $\beta$ receptor (via the Smad $2 / 3$ pathway) and mitogen-activated protein kinase (MAPK) activation after AT receptor stimulation jointly regulate the transcription of target genes (eg, matrix metalloproteinase, MMP; plasminogen-activator inhibitor-1, PAl-1; connective tissue growth factor, CTGF) that result in proliferation, extracellular matrix production/fibrosis, differentiation, and inflammation. AT receptor stimulation additionally upregulates $\mathrm{NAD}(\mathrm{P}) \mathrm{H}$ oxidase (NOX), thereby increasing reactive oxygen species (ROS) formation, which also regulates the transcription of the abovementioned target genes. $\mathrm{AT}_{2}$ receptor stimulation inhibits this pathway by blocking MAPK. AT ${ }_{2}$ receptors also induce vasorelaxation by activating NO synthase (NOS). This may counteract the constrictor effects of AT receptor stimulation (mediated by the inositol trisphosphate $\left[\mathrm{IP}_{3}\right]-\mathrm{Ca}^{2+}$ and diacylglycerol [DAG]-protein kinase C [PKC] pathways). Under pathological condition, ROS uncouple NOS, thereby diminishing NO production and potentially facilitating ROS formation by NOS.

and under certain conditions, for example, in the spontaneously hypertensive rat (SHR), $\mathrm{AT}_{2}$ receptors may become $\mathrm{AT}_{1}$ receptor-like. ${ }^{21,22}$ The mechanism behind this phenotype change is unclear, but most likely involves a difference in location (endothelial cell (EC) versus vascular smooth muscle cell (VSMC)) and heterodimerization with $\mathrm{AT}_{1}$ receptors. Therefore, whether upregulation of $\mathrm{AT}_{2}$ receptors under pathological conditions is always beneficial remains unknown. ${ }^{23}$ Similar opposing findings with regard to $\mathrm{AT}_{2}$ receptor function have been made in the heart. ${ }^{24}$ Of interest,

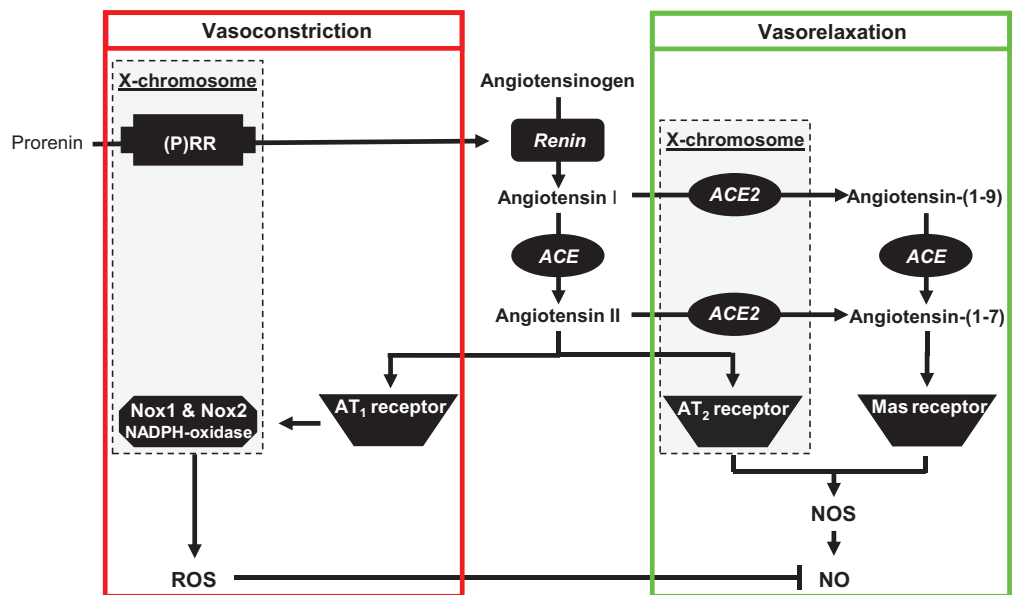

\begin{tabular}{|c||c||c||c||}
\hline \multicolumn{1}{||c||}{} & Men & $\begin{array}{c}\text { Premenopausal } \\
\text { women }\end{array}$ & $\begin{array}{c}\text { Postmenopausal } \\
\text { women }\end{array}$ \\
\hline Sex chromosomes & $\mathrm{XY}$ & $\mathrm{XX}$ & $\mathbf{X X}$ \\
\hline Androgens & +++++ & + & + \\
\hline Estrogens & + & ++++ & + \\
\hline Net effect & Vasoconstriction & Vasorelaxation & Vasoconstriction \\
\hline
\end{tabular}

Figure 4. Vasoconstrictor-vasorelaxant balance of the renin-angiotensin-aldosterone system (RAAS) in relation to sex hormone status in men and pre- and postmenopausal women. The figure highlights X-chromosome-located RAAS genes, including the (pro)renin receptor ((P)RR) gene. The current view is that its relationship with the RAAS may be limited to (pro)renin-synthesizing organs, where (pro)renin is sufficiently high to result in significant receptor binding. 
post myocardial infarction, a moderate cardiac $\mathrm{AT}_{2}$ receptor overexpression in transgenic mice protected against maladaptive remodeling and dysfunction, whereas a massive, 9 -fold overexpression did not yield such positive effects. ${ }^{25}$ Thus, also the degree of overexpression may determine $\mathrm{AT}_{2}$ receptor function.

Wide attention has been paid to the fact that increased vascular Ang II levels increase NAD(P)H oxidase activity in EC, adventitial cells, and VSMC, thereby stimulating reactive oxygen species formation in the vessel wall. ${ }^{26}$ Reactive oxygen species products like superoxide and $\mathrm{H}_{2} \mathrm{O}_{2}$ subsequently activate multiple signaling pathways, involving mitogen-activated protein kinases, tyrosine kinases, phosphatases, calcium channels, and redox-sensitive transcription factors, ${ }^{26,27}$ together resulting in cell growth, expression of proinflammatory genes (eg, transforming growth factor- $\beta$ ), and the production of extracellular matrix proteins, like collagen, elastin, fibrillin, fibronectin, and proteoglycans. The latter production usually involves a phenotype switch in VSMC, from contractile to proliferative/synthetic. In addition, there is an imbalance between apoptosis and growth.

Recent evidence supports a role for the Ang IItransforming growth factor- $\beta$ axis in aneurysm development. ${ }^{28,29}$ Infusion of Ang II in atherosclerotic apolipoprotein E- or LDL receptor KO mice provides an experimental model for the most common type of aneurysm, the abdominal aortic aneurysm. Thoracic aortic aneurysms are less common and often have a genetic background, involving mutations in the above-mentioned extracellular matrix proteins and transforming growth factor- $\beta$. A well-known example is Marfan's syndrome. Losartan was shown to be effective in adults with this syndrome, ${ }^{30}$ and animal data suggest that this effect involves $\mathrm{AT}_{2}$ receptor stimulation rather than $\mathrm{AT}_{1}$ receptor blockade. ${ }^{31}$ Both the transforming growth factor- $\beta$-induced canonical $(\mathrm{pSmad} 2 / 3)$ and noncanonical (mitogen-activated protein kinases) signaling pathways are upregulated in thoracic aortic aneurysms mouse models, and their suppression may underlie the effectiveness of $\mathrm{AT}_{1}$ receptor blockade in these models. ${ }^{31,32}$ As a consequence of these exciting new findings, multiple trials now investigate the effectiveness of RAAS blockers in Marfan's syndrome. ${ }^{29}$ An important issue will be to what degree ACE inhibition (which does not result in $\mathrm{AT}_{2}$ receptor stimulation) differs from $\mathrm{AT}_{1}$ receptor antagonism. One of these trials was recently published. ${ }^{33}$ Involving 608 Marfan patients (age 6 months to 25 years), it did not show superiority of losartan versus the $\beta$-adrenergic antagonist atenolol. Beta-adrenergic antagonists are the current standard therapy in Marfan patients. Here it should be realized that such drugs also suppress renin release. The investigators applied a relatively high dose of atenolol and a low dose of losartan, and there was no placebo group. Moreover, treatment was started in most cases at an advanced stage of the disease. Thus, on the basis of this study, it can be concluded that losartan is a safe alternative for a $\beta$-adrenergic antagonist, but not yet whether (at the appropriate dose and perhaps when given at an earlier stage of development) it might be better.

\section{Sex-Related Aspects}

Physiologically, the 2 major differences between men and women are (1) different levels of sex hormones (testosterone versus estrogen) and (2) the sex chromosome complement (XY versus XX). The combination of a different hormonal milieu and different genes located on the sex chromosomes results in a transcriptome with a sex-specific and sex-biased expression. This leads to a marked sexual dimorphism in anatomy, physiology, and metabolism, but also extends to sex differences in blood pressure (BP), sensitivity to Ang II, and severity of cardiovascular disease. ${ }^{34}$

\section{Sex Hormones}

Premenopausal women have a lower BP in comparison to age-matched men $(\approx 10 \mathrm{~mm} \mathrm{Hg}$ for systolic BP and $\approx 5 \mathrm{~mm} \mathrm{Hg}$ for diastolic BP). Because this sexual dimorphism in BP manifests itself during adolescence and disappears after the menopause, it is logical to assume a role for sex hormones. Testosterone binds to the androgen receptor, whereas estrogen (17 $\beta$-estradiol) stimulates the estrogen receptor $\alpha$ and $\beta$, as well as the G-protein-coupled estrogen receptor-1 (GPER). These receptors mediate both genomic and nongenomic effects. The former involve interaction of the hormone-receptor complex with nuclear DNA, modulating the transcription of sex hormone-responsive genes (taking hours), whereas the latter involves signaling cascades resulting in effects within seconds-minutes. In the case of estrogen, this results in endothelium-dependent and -independent dilator effects through nitric oxide (NO), cGMP, cAMP, and $\mathrm{K}^{+}$-channels. ${ }^{35}$ Testosterone is believed to counteract such endothelium-dependent vasorelaxation and to exert direct constrictor effects ${ }^{35}$; the BP-lowering effects after castration confirmed this view. ${ }^{36}$

In addition, sex hormones affect RAAS components and modulate Ang II sensitivity. Indeed, estrogens increase angiotensinogen, $\mathrm{ACE} 2, \mathrm{AT}_{2}$ receptor density, and endothelial NO synthase, whereas they decrease renin, ACE, AT receptor density, and the NADPH oxidase subunits Nox1 and Nox2 (Figure 4). ${ }^{37,38}$ These alterations are suggestive for an upregulation of ACE2-derived angiotensin-(1-7) formation, enhanced $\mathrm{AT}_{2}$ receptor stimulation and $\mathrm{NO}$ release, combined with reduced reactive oxygen species formation; in other words, they favor the vasodilator arm of the RAAS (see also below). Indeed, low doses of Ang II even decreased $\mathrm{BP}$ in female (but not male) rats, ${ }^{39}$ and higher doses exerted larger BP-increasing effects in males than in females, whereas gonadectomy reversed these effects. ${ }^{40}$ Testosterone increases renin, $\mathrm{ACE}$, and $\mathrm{AT}_{1}$ receptors and downregulates $\mathrm{AT}_{2}$ receptors, thereby favouring the constrictor arm. There are no clear differences in aldosterone levels between men and women. ${ }^{41}$ In postmenopausal women, the balance will shift toward the vasoconstrictor arm, unless they receive hormone replacement therapy. ${ }^{37}$

\section{Sex Chromosomes}

In most mammals, males are heterogametic, possessing $1 \mathrm{X}$ and $1 \mathrm{Y}$ chromosome, whereas females are homogametic with $2 \mathrm{X}$ chromosomes. This characteristic plays a fundamental role in the sexual dimorphism through variances in gene expression. Evolutionary, sex chromosomes have evolved out of 
a pair of matched autosomes, which eventually lost the ability to recombine because of an accumulation of male-specific functions on one chromosome and degradation of nonrecombining regions. ${ }^{42}$ Genes mapped to the $\mathrm{Y}$ chromosome play an important role in sex development, testosterone production, and fertility.

A limited number of studies suggest that sex chromosomes influence BP and regulate RAAS genes. Introgression of the $\mathrm{Y}_{\text {SHR }}$ chromosome from the SHR strain on a normotensive WKY background resulted in a $\approx 20 \mathrm{~mm} \mathrm{Hg}$ BP difference versus rats, where the normotensive $\mathrm{Y}_{\mathrm{WKY}}$ chromosome was introgressed on the SHR background. ${ }^{43}$ The four core genotype mouse model involves the deletion of the sex-determining region $\mathrm{Y}$ (Sry) from the $\mathrm{Y}$ chromosome and the insertion of the Sry transgene onto an autosome, thereby resulting in $\mathrm{XY}^{-}$Sry males. ${ }^{44}$ Crossing these mice to normal $\mathrm{XX}$ females will result in 4 genotypes, $\mathrm{XX}$ gonadal males and females, as well as XY gonadal males and females. Interestingly, Ang II induced a larger BP rise in gonadectomized 4 core genotype mice with an XX genotype than in their XY counterparts independent of prior sex hormone status and gonadal phenotype. ${ }^{45}$ It is tempting to speculate that this mechanism underlies the relatively rapid increase in BP observed in postmenopausal women. ${ }^{46}$ The Sry gene family is known to upregulate angiotensinogen, renin, and ACE, whereas it downregulates ACE2 in vitro. ${ }^{36}$ In addition, the (P)RR, ACE2, Nox1, Nox2, and the $\mathrm{AT}_{2}$ receptor are mapped to the $\mathrm{X}$ chromosome (Figure 4). Although dosage-compensation takes place in women by an epigenetic mechanism called $\mathrm{X}$-inactivation to prevent a lethal dose of X-mapped genes, several genes ( $15 \%$ to $20 \%$ ) have been reported to escape $\mathrm{X}$-inactivation ${ }^{47}$ and contribute to sex differences because of a higher expression in XX than XY cells. ${ }^{48}$ Such escape also applies to the $(\mathrm{P}) \mathrm{RR},{ }^{49,50}$ but the physiological relevance of this observation is still unknown.

\section{Consequences for Treatment?}

It is well-accepted that premenopausal women are protected from the development of cardiovascular disease in comparison to age-matched men. ${ }^{51}$ Obviously, having a higher BP for $\leq 4$ to 5 decades, even when modest, will have consequences. As discussed earlier, animal data support a major role for the RAAS in sex-related differences. Yet, there are no sex-specific recommendations for antihypertensive therapy, nor is there currently any evidence that men and women respond differently to RAAS blockers. One retrospective study in patients with heart failure claimed a higher efficacy of ACE inhibitors in males and of $\mathrm{AT}_{1}$ receptor blockers in females. ${ }^{52}$ Although this potentially supports the importance of $\mathrm{AT}_{2}$ receptor stimulation in women, large prospective studies are warranted to confirm such claims.

\section{Determinants of RAAS Blocker Response and the Degree of Blockade}

\section{Prediction of RAAS Blocker Response}

Although sex, as discussed earlier, is not an established determinant of RAAS blocker response, multiple attempts have been made to predict the response to a RAAS blocker on the basis of alternative parameters. Genetic variation has been evaluated, usually by studying single nucleotide polymorphisms in RAAS genes in a retrospective manner in large clinical trials. ${ }^{53,54}$ Emphasis has been on the ACE insertion/ deletion polymorphism. ${ }^{55}$ Unfortunately, the effects were small and difficult to replicate, and, given the nonexistence of large prospective studies to further evaluate these findings, at this stage, there is no useful genetic information that can be applied to the individual patient to help choosing a specific RAAS blocker.

Along the same lines, it has been argued that patients with high RAAS activity (like patients with bad RAAS gene variants) should preferably be treated with RAAS blockers. Such patients should then be selected on the basis of their high renin, ACE, and aldosterone levels. Ang II levels might also be useful, but given the technical difficulties to measure this RAAS component, this is currently not feasible. The background of this concept is that patients with high baseline RAAS activity have a higher risk to develop cardiovascular disease. Indeed, retrospective analyses of patient populations in clinical trials in whom baseline renin measurements were available support that high renin levels are indicative of future cardiovascular disease and death, particularly in patients with kidney dysfunction, and hypertension. ${ }^{56-59}$ Remarkably, this relationship was not affected by the use of RAAS blockers, which, through interference with the negative feedback loop between Ang II and renin, increase renin release. Obviously, renin measurements, when based on activity, will be disturbed by the use of renin inhibitors, and thus during such treatment only measurements of plasma renin concentration, and not plasma renin activity, will give an indication of the true renin levels. In addition, salt intake affects renin secretion, with patients on a low salt diet displaying higher renin levels. Preferably therefore, when considering pretreatment renin levels as a treatment determinant, salt intake should be taken into account.

Laragh and Sealey distinguish a low renin, sodium volumedependent form of essential hypertension and a medium-tohigh renin form of hypertension. ${ }^{60}$ The former occurs whenever body sodium content increases beyond the point where plasma RAAS activity is turned off, whereas the latter occurs when too much renin is secreted relative to the body sodium content. Antihypertensive treatment should then be aimed at reducing either body salt and volume content (diuretics, calcium antagonists) or RAAS activity (RAAS blockers and $\beta$-adrenergic antagonists; the latter suppress renin release). Retrospective analyses of BP trials confirmed this concept. ${ }^{61,62}$ In addition, Gupta et al observed that African Americans, who on average have lower renin levels compared with Caucasians, ${ }^{63}$ responded less well to atenolol. ${ }^{64}$ Yet, others observed either no role for baseline renin, ${ }^{65}$ or at most a weak trend. ${ }^{66-68}$ Moreover, the BP decreases for a given baseline renin level (uncorrected for salt intake) varied $>40 \mathrm{~mm} \mathrm{Hg}$. In addition, a uniform definition of high renin (plasma renin activity/plasma renin concentration) is not available and clearly complicated by the intake of salt, sex, ethnicity, and the use RAAS-affecting drugs. ${ }^{61,65,67}$ Thus, although in general it is probably true that patients with high renin levels respond better to RAAS blockers (for instance, patients pretreated with a diuretic, which activates the RAAS), 
the variation in renin is such (not even taking into consideration the additional variation at the tissue level!) that it is of limited practical use for the individual patient. Unfortunately, the same is true for plasma ACE. ${ }^{69}$ The use of aldosterone measurements will be discussed below.

\section{Desired Degree of RAAS Blockade}

Given the Ang II/aldosterone escape during RAAS blocker treatment, usually occurring within days-weeks after drug initiation, ${ }^{70}$ for many years it was argued that the more blockade, the better, to keep the levels of these active components (or their activity) low. Nevertheless, early animal studies in SHR ${ }^{71}$ had already shown that dual RAAS blockade, particularly under low-salt conditions (when the RAAS is most needed) is lethal: it caused a major decrease in BP and severe renal failure, which were accompanied by massive rises (up to several 100 -fold) in plasma renin and renal renin levels, thereby decreasing the angiotensinogen concentration in plasma. These deleterious effects of dual RAAS blockade were prevented by a high salt diet. Studies in human cardiac tissue, obtained from patients undergoing cardiac transplantation or severe heart failure patients at the time of left ventricular assist device implantation, ${ }^{72,73}$ both being treated with (high) RAAS blocker doses, revealed that also in the human heart renin levels may rise $>100$-fold, thereby decreasing cardiac angiotensinogen. Interestingly, after left ventricular assist device implantation, renin levels dropped 10-fold and cardiac angiotensinogen levels rose again, thereby allowing a rise in cardiac Ang II levels. ${ }^{73}$ This illustrates the fact that at high renin levels, angiotensinogen depletion essentially renders Ang II generation impossible.

Taken together, these data illustrate that too much RAAS blockade annihilates the capacity of tissues to acutely generate Ang II when necessary. Particularly in the kidney, this may be crucial to preserve glomerular filtration. Recent data obtained in salt-depleted healthy volunteers exposed to increasing doses of a new renin inhibitor, VTP-27999, provide further evidence for this concept. ${ }^{74}$ To fully appreciate these data, it should be mentioned that renin inhibitors selectively accumulate in the kidney, remaining present in renal tissue at high levels, even at days-weeks after stopping treatment, when plasma levels are undetectable. ${ }^{75,76}$ It was observed that at the highest dose of VTP-27999 tested $(600 \mathrm{mg})$, the drug blocks the renal RAAS more effectively than the circulating RAAS. Indeed, when stopping drug intake after 10 days of dosing, the plasma renin concentration levels at 24 to 72 hours after the last dose exceeded the capacity of extrarenal VTP-27999 to fully block renin's enzymatic activity (Figure 5). Therefore, even though the intrarenal RAAS is still inhibited at these times, extrarenal RAAS activation now occurred, increasing the circulating concentrations of Ang II and aldosterone. These findings are reminiscent of the nephrocentric view of ACE inhibition noted 25 years ago in patients with congestive heart failure. ${ }^{77}$ It was asked why the kidneys continue to release renin in such patients; the answer being that they do everything possible to preserve renal function and glomerular filtration, apparently at the expense of the hemodynamic burden on the heart. Exactly this happened in the VTP-27999 study, where the kidneys responded to excessive renal RAAS suppression by releasing large quantities of renin, resulting in elevations of plasma renin activity, Ang II, and aldosterone. Such elevated Ang II levels were most likely responsible for the (nonsignificant) increase in heart rate observed in the subjects treated with $600 \mathrm{mg}$ VTP-27999. Clearly therefore, renin inhibition has an upper limit and more is not always better.

The latter also applies to other types of excessive RAAS blockade (eg, when combining an ACE inhibitor and an $\mathrm{AT}_{1}$ receptor antagonist): several large dual RAAS blockade studies (ONTARGET, ALTITUDE, NEPHRON-D) ${ }^{78-80}$ in a variety of patients all concluded that the adverse effects (hypotension, hyperkalemia, and renal dysfunction), all because of (renal) Ang II depletion, outweighed the beneficial effects. In reaching this conclusion, it should be realized that often these patients additionally took $\beta$-adrenergic antagonists and MR antagonists and thus were in reality not exposed to dual but to quadruple RAAS blockade. This led Nussberger and Bohlender to conclude that the goal should not be maximal but optimal RAAS blockade, guided by regularly measuring $\mathrm{BP}$, serum potassium, and creatinine. ${ }^{81}$

Recent guidelines no longer recommend the combined use of ACE inhibitors, $\mathrm{AT}_{1}$ receptor blockers, and renin inhibitors in hypertension. ${ }^{82}$ Most evidence is obviously available for the ACE inhibitors. As explained earlier, there is still discussion to what degree the $\mathrm{AT}_{2}$ receptor stimulation during $\mathrm{AT}_{1}$ receptor blockade is beneficial or harmful. Two recent metaanalyses show that ACE inhibitors reduce all-cause mortality and cardiovascular death in patients with hypertension and diabetes mellitus, whereas $\mathrm{AT}_{1}$ receptor blockers do not. ${ }^{83,84}$ This may relate to the possibility that $\mathrm{AT}_{2}$ receptor stimulation affects the incidence of myocardial infarction ${ }^{85,86}$ and induces apoptosis in intestinal epithelial cells, thereby inducing severe gastrointestinal problems. ${ }^{87,88}$ Additionally, $\mathrm{AT}_{2}$ receptor stimulation activates the bradykinin axis, ${ }^{89}$ although bradykinin accumulation will also occur after ACE inhibition. The exact contribution of bradykinin to the beneficial effects of RAAS blockade in humans remains to be determined. Nevertheless, based on these findings, it is clear that ACE inhibitors should be considered as first-line agents in patients with hypertension and diabetes mellitus.

Aldosterone
Aldosterone is a steroid hormone produced in the zona glo-
merulosa of the adrenal gland. Like Ang II, aldosterone is an
effector hormone of the RAAS, principally involved in vol-
ume and BP regulation. Beyond BP, aldosterone has emerged
as a cardiovascular risk factor promoting cardiovascular and
renal inflammation, fibrosis, and remodeling. Furthermore, in
cohort studies of nonhypertensive individuals, higher circulat-
ing aldosterone levels, but still within the physiological range,
are a risk factor for the development of hypertension..$^{90}$ With
regard to hypertension, the importance of aldosterone is large-
ly related to primary aldosteronism and treatment-resistant
hypertension. The mechanism of action of aldosterone was
thought to be restricted to its renal genomic effects, causing
sodium and water retention. More recently, evidence has accu-
mulated for effects of aldosterone on EC and VSMC that may
or may not be mediated by the MR. ${ }^{91-93}$ In the first part of this



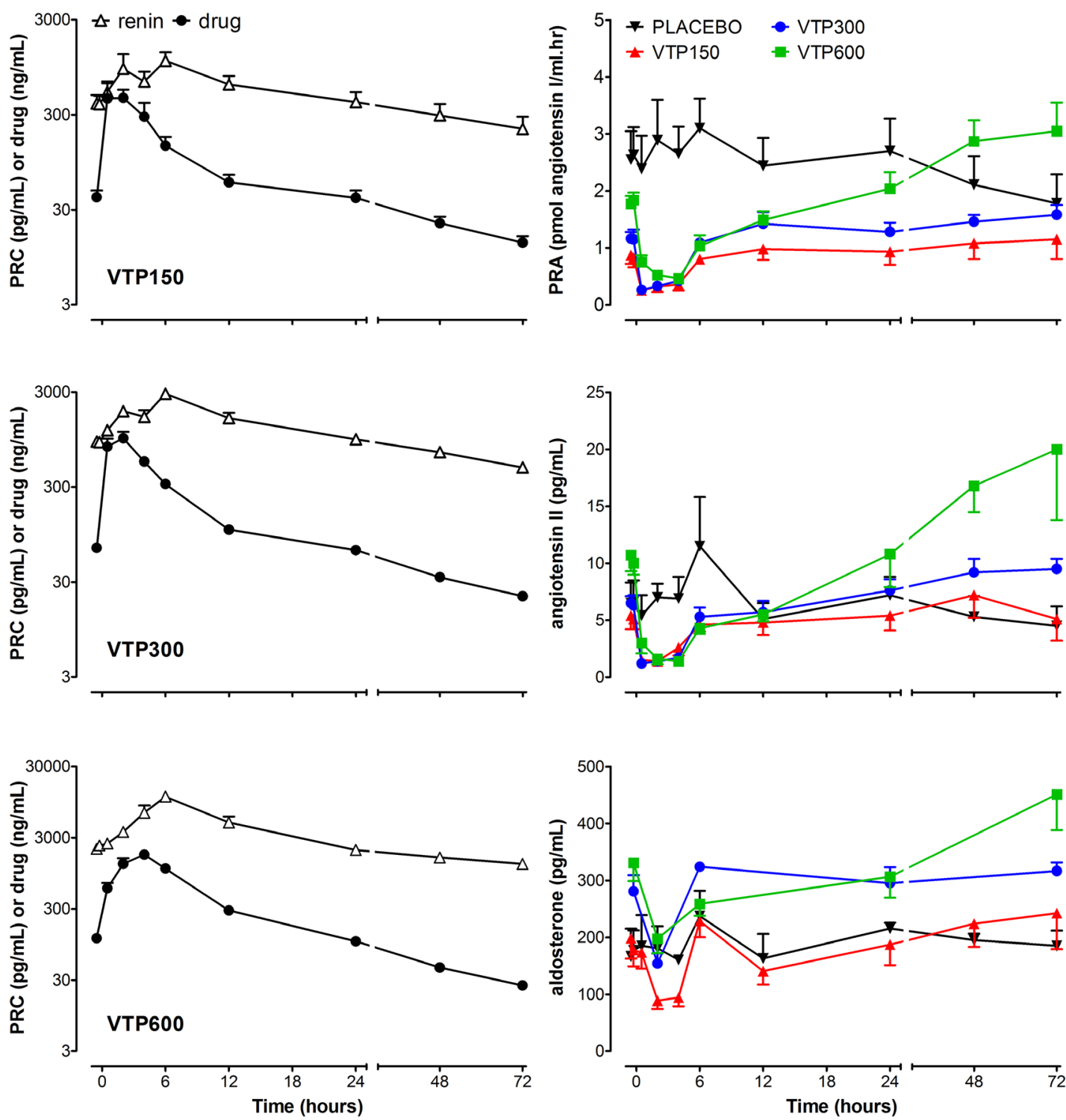

Figure 5. The consequences of too much renin inhibition (with the new renin inhibitor VTP-27999), as observed after stopping treatment. Normally, the decrease in plasma drug level and renin concentration after stopping run in parallel. However, after a high (600 $\mathrm{mg}$ ) dose of VTP-27999 (which, like aliskiren, is known to accumulate in the kidney ${ }^{76}$ ), plasma renin suppression lags behind the decline in plasma drug decrease, most likely because the renal renin-angiotensin-aldosterone system (RAAS) is still suppressed, thus keeping renin release at a (too) high level, which can no longer be suppressed by VTP-27999 in plasma. As a consequence, plasma renin activity, Ang II, and aldosterone rise above control levels. In other words, too much renin inhibition, by excessively blocking the renal RAAS, may effectively activate extrarenal RAAS activity. Data derived from Balcarek et al. ${ }^{74}$

section, we focus on new insights in the potential vascular effects of aldosterone and the receptors involved. In the second part, new developments in the pathogenesis and etiology of primary aldosteronism and the role of aldosterone in resistant hypertension will be reviewed.

\section{Aldosterone, Aldosterone Receptors, and Sodium Channels}

Aldosterone is synthesized from cholesterol in the zona glomerulosa of the adrenal gland by a series of enzymatic reactions. The final steps of aldosterone synthesis are catalyzed by aldosterone synthase encoded by the gene CYP11B2 located on chromosome 8q21-22. Classic stimulators of aldosterone biosynthesis are Ang II, extracellular potassium concentration, and ACTH. Vascular endothelial growth factor has recently emerged as a stimulator of aldosterone production. ${ }^{94}$ Stimulation by these factors results in activation of aldosterone synthase induced by an increase in intracellular calcium concentration. ${ }^{95}$

Aldosterone classically works in a genomic way through the induction and modulation of gene transcription with the cytoplasmatic/nuclear MR within the renal cortical collecting duct cells as its main target. After binding of aldosterone to the MR, causing dissociation of chaperones and formation of MR dimers, this complex translocates to the nucleus, resulting in increased expression of several intracellular kinases, including serum- and glucocorticoid-induced kinase 1, Kirsten Ras GTP-binding protein 2A, and WNK4. This process leads to 
increased expression of the luminal located epithelial sodium channel, renal outer medullary $\mathrm{K}^{+}$-channels, and the basolaterally located $\mathrm{Na}^{+} / \mathrm{K}^{+}$-ATPase. ${ }^{96}$ Increased renal epithelial sodium channel activity promotes renal $\mathrm{Na}^{+}$reabsorption, resulting in volume expansion and a rise in BP.

Additionally to its expression in renal collecting duct cells, the MR is also expressed in ECs and VSMCs. ${ }^{92,93}$ Important new insight in the role of the VSMC-MR has been obtained by engineering a mouse with an inducible, selective deletion of VSMC-MR. ${ }^{97}$ In these KO mice, BP at young age is similar as in wild-type control mice, but, despite intact renal MR receptors, the age-related rise in $\mathrm{BP}$ is attenuated. Furthermore, aged VSMC-MR-KO mice have a decreased vascular tone, and the aged vessels exhibit decreased contractile responses to thromboxane, Ang II, and calcium channel agonists. ${ }^{97}$ Moreover, these mice have an attenuated increase in BP and superoxide production to Ang II infusion and a decrease in large-artery stiffness after aldosterone salt challenge compared with wild-type mice. ${ }^{98}$

Several new molecular pathways activated by the interaction of aldosterone with the VSMC-MR and contributing to vascular remodeling have been described in the past several years. ${ }^{98-100}$ These pathways promote vascular inflammation, fibrosis and VSMC hypertrophy, and proliferation and may contribute to the development of large artery stiffness. Although the clinical implication of these pathways requires further research, it has already been shown in patients with familial hyperaldosteronism type I that cardiac and vascular damage may precede the development of hypertension. ${ }^{101}$

In ECs, aldosterone increases the expression of endothelial $\mathrm{Na}$ channels in a MR-dependent way that can be blocked by spironolactone. ${ }^{102}$ Increased endothelial Na channel activity in combination with a high plasma sodium leads to stiffening of the cortex of ECs caused by an increase in sodium influx. A direct consequence of this stiffening is a decrease in endothelial NO synthase-mediated NO release. ${ }^{103}$ Thus, high aldosterone in combination with high salt intake may result in endothelial dysfunction, which may contribute to a rise in BP independent of the renal effects of aldosterone.

Besides its genomic effects mediated by stimulation of the MR receptors in the kidney and vasculature, rapid nongenomic effects of aldosterone have also been reported. ${ }^{91}$ These nongenomic effects of aldosterone may be mediated by GPER..$^{91,104}$ GPER is a widely distributed receptor, also identified in EC and VSMC. ${ }^{105}$ GPER in cultured EC and VSMC can be stimulated by estrogen but also by aldosterone at picomolar concentrations. ${ }^{91}$ Aldosterone-induced activation of aortic vascular ECs via GPER leads to vasodilation as well as to proapoptotic and antiproliferative effects. ${ }^{104}$ These effects of aldosterone are blocked by the GPER receptor antagonist G15. Whether aldosterone also exerts effects on VSMCs through activation of the GPER is uncertain, as GPER expression is no longer present when aortic VSMCs are cultured. ${ }^{91}$ GPER seems to play a role in the potentiation of Ang II-induced vasoconstriction by aldosterone because this potentiation could be blocked by G15, but not by the MR-antagonist eplerenone. ${ }^{106}$

\section{Sporadic and Familial Primary Aldosteronism}

Primary aldosteronism (PA) is characterized by excessive autonomous aldosterone secretion by the adrenal gland. The consequent volume expansion and hypertension leads to renin suppression, and accordingly the ARR has been advocated as a screening test for PA. ${ }^{107}$ Among hypertensive individuals, the prevalence of PA is high, ranging from $4.3 \%$ in a primary care setting to $9.0 \%$ of referred patients and to $20 \%$ of those with therapy-resistant hypertension. ${ }^{108}$ We and others have shown that the sensitivity of the ARR as a screening test for PA is relatively poor, which may relate to the way patients were selected and to overestimation of the true renin concentration by the nowadays commonly used direct renin assay (because of codetection of prorenin) instead of plasma renin activity measurements. ${ }^{109,110}$

PA can be divided in frequent sporadic and rare familial forms. Familial hyperaldosteronism (FH) type 1, also known as glucocorticoid-remediable aldosteronism, is an autosomal dominant disease caused by a recombination between the CYP11B2 and CYP11B1 (the latter being responsible for cortisol synthesis) genes, creating a chimeric gene whereby the CYP11B1 promotor and CYP11B2 coding sequences are juxtaposed. In FH-I, aldosterone synthesis is regulated by ACTH rather than by Ang II. Administration of glucocorticoids (thereby suppressing ACTH) reduces aldosterone levels, and the lowest dose of glucocorticoids normalizing BP is the treatment of choice. The cause of FH-II has yet to be identified. FH-II is diagnosed if $\geq 2$ members of one family are affected. Adenomas as well as bilateral hyperplasia may underlie FH-II. The first family with FH-III has been described in 2008. ${ }^{111}$ The affected family members presented with severe hypertension and hypokalemia at young age and in contrast to FH-I aldosterone could not be suppressed by dexamethasone. FH-III appeared to be caused by a mutation in the KCNJ5gene, encoding for the G-protein-activated inward rectifier potassium channel Kir3.4. ${ }^{112}$ This mutation results in the loss of $\mathrm{K}^{+}$-selectivity and increased $\mathrm{Na}^{+}$conductance, leading to membrane depolarization of the zona glomerulosa cell with subsequent opening of voltage-dependent calcium channels and activation of the calcium-signaling pathway (Figure 6). Several other mutations in the KCNJ5 gene causing FH-III, not always accompanied by a severe phenotype as described for the first cases, have been reported. ${ }^{113}$ In addition to the germline mutations causing FH-III, somatic KCNJ5 mutations, resulting in loss of the selectivity filter of Kir3.4 channel, have been identified in surgically removed aldosterone-producing adenomas (APAs). These mutations are present in $\leq 47 \%$ in APAs from Western populations and $\leq 65 \%$ from a Japanese population. ${ }^{95}$ In addition, several other less frequently occurring somatic mutations in 2 members of the P-type ATPase gene family (ATP1A1 and ATP2B3) and in CACNA1D (encoding for the voltage-gated $\mathrm{Ca}^{2+}$ channel $\mathrm{Ca}_{\mathrm{v}} 1.3$ ) have been identified (Figure 6). ${ }^{114,115}$ In adrenal glomerulosa cells, mutations in ATP1A1 result in inappropriate depolarization, mutations in ATP2B3 in decreased intracellular calcium clearance, and mutations in CACNA1D in increased $\mathrm{Ca}^{2+}$ influx. In 308 APAs, negative for KCNJ5 mutations, 5.2\% somatic mutations in ATP1A1 and 1.6\% mutations in ATP2B3 have been identified. ${ }^{95}$ CACNA1D mutations may occur in $\leq 11 \%$ of APAs. ${ }^{116}$ Interestingly, KCNJ5 mutations are common in APAs resembling the cortisol-secreting cells of the zona fasciculata, 


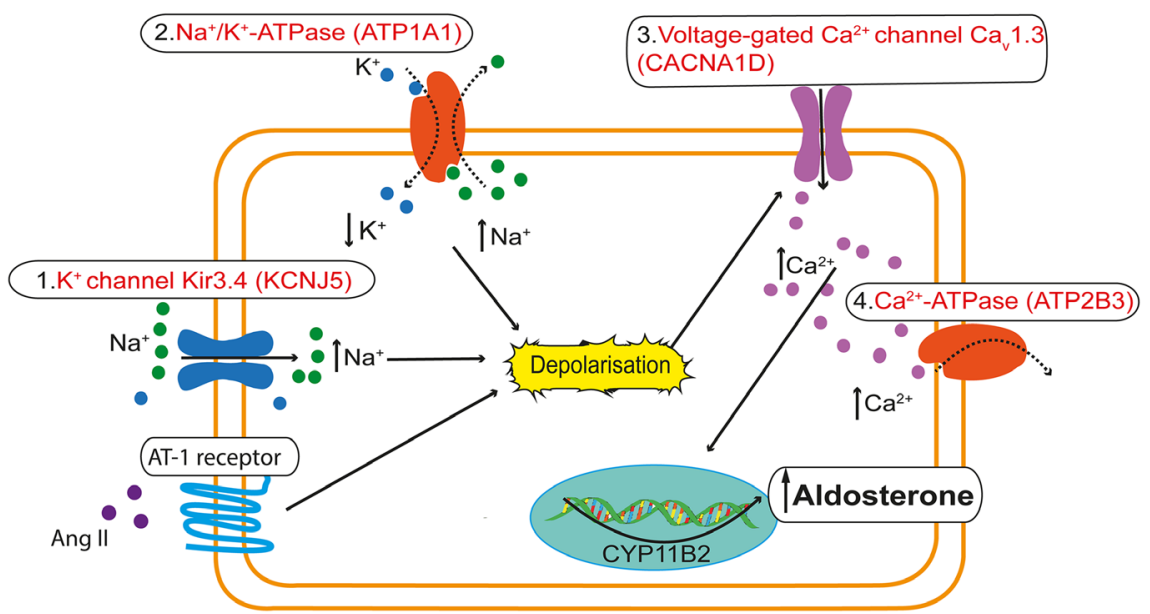

Figure 6. Mutations in ion channels (encoded by the genes KCNJ5, ATP1A1, CACNA1D, and ATP2B3) of the adrenal glomerulosa cell that have recently been linked to excessive aldosterone production. Normally, $A T_{1}$ receptor activation induces depolarization as a result of inactivation of the potassium channel Kir3.4 and $\mathrm{Na}^{+}, \mathrm{K}^{+}$-ATPase. Such depolarization triggers $\mathrm{Ca}^{2+}$-influx via voltagegated $\mathrm{Ca}^{2+}$ channels $\left(\mathrm{Ca}_{v} 1.3\right)$, and the resultant rise in intracellular $\mathrm{Ca}^{2+}$ activates the aldosterone synthase gene CYP11B2. Ca ${ }^{2+}-\mathrm{ATPase}$ subsequently removes $\mathrm{Ca}^{2+}$ from the cell. KCNJ5 mutations affect the selectivity of the Kir3.4, now also allowing $\mathrm{Na}^{+}$conductance. Similarly, mutations in ATP1A1 result in loss of pump activity and strongly reduced affinity for potassium, thereby increasing intracellular $\mathrm{Na}^{+}$. Increased $\mathrm{Na}^{+}$levels cause depolarization, even in the absence of $\mathrm{AT}_{1}$ receptor stimulation. Mutations in CACNA1D facilitate Ca ${ }^{2+}$ influx, whereas mutations in ATP2B3 hamper its removal from the cell, thus both elevating intracellular $\mathrm{Ca}^{2+}$. This activates CYP11B2 transcription.

whereas mutations in P-type ATP-ases and CACNA1D have been found in small zona glomerulosa cell APAs. ${ }^{115}$ These genotype-phenotype correlations might hopefully be of clinical use in the near future.

\section{Aldosterone and Resistant Hypertension}

Resistant hypertension is defined as uncontrolled hypertension, despite therapy with 3 drugs, including a diuretic, or BP elevations requiring $\geq 4$ drugs for control with an estimated prevalence of $10 \%$ to $15 \%$ of hypertensive patients treated. ${ }^{117}$ PA, because of its high prevalence, can underlie resistant hypertension, but also in patients without PA, BP control was lower in patients with an elevated ARR and higher aldosterone levels. ${ }^{18}$ That aldosterone plays a role in resistant hypertension is supported by trials showing that addition of MR blockers to usual antihypertensive treatment can sometimes produce pronounced BP reductions. ${ }^{119}$ In an open-label study, addition of spironolactone 25 to $100 \mathrm{mg}$ per day to $175 \mathrm{pa}-$ tients with true resistant hypertension to existing antihypertensive therapy reduced ambulatory BP by $16 / 9 \mathrm{~mm} \mathrm{Hg} .{ }^{120}$ The mechanism of the BP-lowering effect of MR antagonists in resistant hypertension is incompletely understood because indices of aldosterone excess, such as low renin or high ARR or a low serum potassium, do not predict the response to aldosterone receptor blockers. ${ }^{121}$ Spironolactone-mediated inhibition of central sympathetic nervous system activity has been proposed as one of the mechanisms. ${ }^{122}$ Furthermore, reduction of vascular stiffness and improvement of endothelial function by blockade of vascular MRs may be involved.

\section{Protective Arms of the RAAS: Can We Expect New RAAS Drugs?}

All current RAAS blockers interfere with the renin-ACE$\mathrm{AT}_{1}$ receptor-aldosterone axis. Aldosterone synthase inhibitors are being considered an alternative for MR antagonists, ${ }^{123}$ but such drugs would obviously also interfere with this pathway. Three new RAAS pathways have been discovered in the last 2 decades, which might be of interest for future drug development: (1) $\mathrm{AT}_{2}$ receptor stimulation, (2) stimulation of ACE2-Ang-(1-7)-Mas receptor signaling, and (3) modulation of angiotensin III and IV signaling. In addition, drugs are being developed which block the RAAS plus an additional hormonal system, for example, combined $\mathrm{AT}_{1}$ receptor blockers/neprilysin inhibitors, which prevent the degradation of natriuretic peptides (by neprilysin) and combined $\mathrm{AT}_{1}$ receptor/ endothelin-1 receptor antagonists. Their discussion is beyond the scope of this review.

\section{$\mathrm{AT}_{2}$ Receptor Stimulation}

As discussed earlier, the $\mathrm{AT}_{2}$ receptor is generally considered to have effects that are opposite to those of the $\mathrm{AT}_{1}$ receptor. Its presumed endogenous ligands are Ang II, Ang III, Ang IV, and Ang-(1-7) in order of highest to lowest affinity (Figure 1). ${ }^{124}$ Ang III seems to be the preferred agonist for $\mathrm{AT}_{2}$ receptors. ${ }^{125-127}$ For reasons that are still unclear, $\mathrm{AT}_{2}$ receptor-mediated vasodilation is best detected under partial $\mathrm{AT}_{1}$ receptor blockade, and the same may apply to its natriuretic, antifibrotic, and anti-inflammatory effects in the kidney. ${ }^{125,128-130} \mathrm{AT}_{2}$ receptor KO mice display an increased $\mathrm{BP}$, worsened pressure-natriuresis, increased baroreflex sensitivity, increased responsiveness to hypertensive stimuli ( $\mathrm{NO}$ synthase inhibition), and decreased cardiac and vascular $\mathrm{AT}_{1}$ receptor expression. ${ }^{131-133} \mathrm{AT}_{2}$ receptor overexpression shows the opposite. ${ }^{134}$ It therefore seemed logical to develop specific $\mathrm{AT}_{2}$ receptor agonists.

Currently, 4 candidate drugs for clinical development have been identified, namely the peptidergic agonists $\beta$-Tyr4-Ang II, $\beta$-Ile5-Ang II, and LP2-3 and the nonpeptide agonist Compound 21 (C21). ${ }^{130,135} \beta$-Tyr4-Ang II and $\beta$-Ile5-Ang II are Ang II analogues in which the Tyr4 and Ile5 $\alpha$-amino acid 
residues have been replaced by $\beta$-amino acids, that is, amino acids containing an additional methylene group. ${ }^{130}$ This results in an almost complete loss of $\mathrm{AT}_{1}$ receptor affinity, a modest ( $\approx 5$ - to 15-fold) decrease in $\mathrm{AT}_{2}$ receptor affinity and an increased stability. Both peptide agonists caused weak, $\mathrm{AT}_{2}$ receptor-mediated, NO-dependent vasorelaxation in the mouse aorta. In addition, $\beta$-Ile5-Ang II lowered BP in SHR during coinfusion with candesartan. ${ }^{130}$

LP2-3 is cyclic Ang-(1-7) (see below) with a D-lysine $\mathrm{N}$-terminal extension. ${ }^{135}$ Although it inhibits pathological remodeling of lung, cardiac, and vascular tissue in a model of hyperoxia-induced neonatal pulmonary dysplasia, ${ }^{135}$ there is currently no proof of its claimed $\mathrm{AT}_{2}$ receptor agonistic activity. Much more is known about C21, which is expected to enter the clinical phase of development this year. ${ }^{136}$ Confusingly, despite the wealth of data on $\mathrm{AT}_{2}$ receptor-mediated vasodilation, $\mathrm{C} 21$ has either no effect on BP or even increases BP. ${ }^{129,136,137}$ The latter may relate to the fact that, for instance in SHR, $\mathrm{AT}_{2}$ receptors become $\mathrm{AT}_{1}$ receptor-like (ie, constrictor), whereas at exceptionally high doses, $\mathrm{C} 21$ also activates $\mathrm{AT}_{1}$ receptors. ${ }^{21,137}$ In vitro, $\mathrm{C} 21$ has a weak vasodilator effect, particularly observed during $\mathrm{AT}_{1}$ receptor blockade, at concentrations above its $\mathrm{K}_{\mathrm{d}}{ }^{138} \mathrm{In}$ fact, because such effects were also observed in vessels of $\mathrm{AT}_{2}$ receptor $\mathrm{KO}$ mice, it has been proposed that $\mathrm{C} 21$ has pleiotropic effects; its ability to block vasoconstriction to nonangiotensin constrictors further confirmed this view. ${ }^{137}$ In summary, although $\mathrm{C} 21$ does not seem to be an appropriate antihypertensive drug, the antifibrotic and anti-inflammatory effects of $\mathrm{AT}_{2}$ receptor stimulation warrant alternative indications, including Marfan's syndrome. ${ }^{31}$

Because $\mathrm{AT}_{2}$ receptors also stimulate neurite outgrowth, thereby facilitating pain, ${ }^{139}$ a recent clinical trial has investigated to what degree $\mathrm{AT}_{2}$ receptor antagonists might be applied in neuropathic pain. Indeed, already after 3 weeks, such drugs reduced pain in patients with postherpetic neuralgia. ${ }^{140}$ Whether this outcome affects the future application of $\mathrm{AT}_{2}$ receptor agonists cannot yet be said.

\section{ACE2-Ang-(1-7)-Mas receptor Axis}

Ang-(1-7), mainly produced from Ang II by ACE2 (Figure 1), opposes $\mathrm{AT}_{1}$ receptor-mediated effects via its binding to the Mas receptor. ${ }^{141}$ Yet, it also binds $\mathrm{AT}_{2}$ receptors and, at high concentrations, even acts as a partial $\mathrm{AT}_{1}$ receptor agonist. ${ }^{142}$ A plethora of beneficial cardiovascular effects has been described for Ang-(1-7) in the past 25 years. These include protection against heart failure, natriuretric, antithrombotic, antihypertrophic, antifibrotic, and antiarrhythmic effects, attenuation of plaque formation, and amelioration of metabolic syndrome-related vascular dysfunction. ${ }^{129,143}$ It has weak vasodilator effects, which have not uniformly been confirmed. Ang-(1-7) also stimulates the production of endothelial progenitor cells (and tube formation thereof), but simultaneously inhibits tube formation by adult EC. ${ }^{129,143}$ The circumstances under which the BP-lowering effects of Ang-(1-7) have been investigated varied widely (species, models, cotreatment with RAAS blockers/NO synthase inhibitors, salt intake) so that even now it cannot be stated with certainty that Ang-(1-7) is an antihypertensive agent. Similarly, although ACE2 overexpression does lower BP, this may be simply because of its capacity to degrade Ang II (rather than its generation of Ang$(1-7)) .{ }^{144}$ Even more worryingly, the putative ACE2 activators 1-[(2-dimethylamino) ethylamino]-4-(hydroxymethyl)-7-[(4methylphenyl) sulfonyl oxy]-9H-xanthene-9-one (XNT) and diminazene were recently shown to act fully independently from either ACE2 or Ang-(1-7), thus questioning whether their in-vivo effects have anything to do with this pathway. ${ }^{145}$

Despite these controversies, stimulation of the ACE2-Ang(1-7)-Mas receptor axis might still be an interesting therapeutic option. In view of the rapid breakdown of Ang-(1-7) (as well as its $\mathrm{AT}_{1}$ receptor agonistic properties at high concentrations), alternative strategies have been developed. These are oligosaccharide (hydroxypropyl $\beta$-cyclodextrin)-encapsulated Ang-(1-7), Ang-(1-7) peptide stabilization by thioether bridging (creating so-called cyclic Ang-(1-7)), NorLeu3Ang-(1-7), the peptide drug CGEN856S, and the nonpeptide drug AVE0991. ${ }^{129,146}$ Cyclodextrin-encapsulated Ang-(1-7), AVE0091, and CGEN856S have shown BP-lowering effects in hypertensive animals, whereas the other agonists have not been tested yet in such a setting. Clearly, much more work is needed before these drugs can enter the clinic, although NorLeu3-Ang-(1-7) has been used clinically to treat foot ulcers in diabetic patients. ${ }^{147}$

\section{Blockade of Ang III and Ang IV}

As discussed earlier, Ang III is believed to act as an $\mathrm{AT}_{2}$ receptor agonist, for example, in the kidney and vessel wall. Yet, in the brain, it has been proposed to be the preferred $\mathrm{AT}_{1}$ receptor agonist, thus causing hypertension. ${ }^{148}$ On this basis, aminopeptidase A inhibitors (which block the conversion of Ang II to Ang III) are now being developed, which act exclusively in the brain. Indeed, RB150 (4,4'-dithio[bis(3S)-aminobutyl sulfonic acid]) is a prodrug that, after crossing the blood-brain barrier, is converted to the aminopeptidase A inhibitor EC33 ((3S)-3-amino-4-sulfanyl-butane-1-sulfonic acid). ${ }^{149}$ RB150 can be delivered orally and has already shown antihypertensive and cardioprotective properties in animal models, so that it is now under evaluation in a phase Ib clinical study. ${ }^{150}$

To what degree the aminopeptidase $\mathrm{N}$ product of Ang III, that is, Ang IV, has a function in BP regulation remains unclear. At high (micromolar) concentrations, it binds to $\mathrm{AT}_{1}$ and $\mathrm{AT}_{2}$ receptors, resulting in both constrictor and relaxant effects, the former possibly involving endothelin-1..$^{151,152}$ However, the relevance of these observations, given its low (femtomolar) concentrations in vivo, is questionable. Instead, high potency effects of Ang IV may rather involve its binding to insulin-regulated aminopeptidase (IRAP), also known as the $\mathrm{AT}_{4}$ receptor (please note that $\mathrm{AT}_{3}$ receptors do not exist, the 4 refers to Ang IV). ${ }^{153}$ Unfortunately, even this concept has recently been challenged, ${ }^{154}$ leaving as a final option the observation that Ang IV binds with high affinity to $\mathrm{AT}_{1}$ receptors that are constitutively active, that is, that already display activity without agonist binding. ${ }^{155}$ Until today the physiological relevance of this phenomenon is unknown.

\section{Conclusions}

Tissue angiotensin generation depends on kidney-derived renin and hepatic angiotensinogen, occurs extracellular, and is followed by rapid AT receptor binding and internalization. 
Locally generated Ang II affects the constrictor/relaxant balance, vascular remodeling, and inflammation. Tissue angiotensin generation does not necessarily run in parallel with angiotensin generation in the circulation, and this explains why the beneficial effects of RAAS blockers cannot be simply explained on the basis of changes in the circulating RAAS. Sex, ethnicity, salt intake, genetic variation, and the use of antihypertensive drugs determine the degree of RAAS activity, and although in general high RAAS activity (as evidenced by high plasma renin levels) would be supportive for the application of RAAS blockers, the interindividual RAAS component variation is such that it is impossible to exactly define high or low renin levels that warrant the choice for a certain RAAS blocker. Too much RAAS blockade yields effects that can be expected when removing Ang II/aldosterone (hypotension, hyperkalemia, renal dysfunction), and thus the goal should be to obtain optimal instead of maximal RAAS blockade, guided by regularly measuring BP, potassium, and creatinine. Aldosterone unexpectedly has a wide range of extrarenal effects, among others in EC and VSMC, and these are not necessarily all mediated via the MR. Together with the many mutations that have recently been discovered in genes encoding for proteins that control sodium, potassium, and calcium ion homeostasis in adrenal cells (with strong resultant effects on aldosterone synthesis), this explains the revived interest in drugs that block aldosterone, for example, in resistant hypertension. In addition, the discovery of the relaxant, protective arms of the RAAS, involving $\mathrm{AT}_{2}$ and Mas receptor stimulation, may yield new drugs that can be applied in the future on top of the existing RAAS blockers in patients with cardiovascular and renal disorders.

\section{Sources of Funding}

A.J.M. Roks was supported by a grant of the Netherlands Heart Foundation (NHS2010B009).

\section{Disclosures}

None.

\section{References}

1. Nussberger J, Brunner DB, Waeber B, Brunner HR. Specific measurement of angiotensin metabolites and in vitro generated angiotensin II in plasma. Hypertension. 1986;8:476-482.

2. van den Meiracker AH, Admiraal PJ, Janssen JA, Kroodsma JM, de Ronde WA, Boomsma F, Sissmann J, Blankestijn PJ, Mulder PG, Man In 't Veld AJ. Hemodynamic and biochemical effects of the AT1 receptor antagonist irbesartan in hypertension. Hypertension. 1995;25:22-29.

3. Danser AH. Cardiac angiotensin II: does it have a function? Am J Physiol Heart Circ Physiol. 2010;299:H1304-H1306. doi: 10.1152/ ajpheart.00881.2010.

4. Urata H, Healy B, Stewart RW, Bumpus FM, Husain A. Angiotensin II-forming pathways in normal and failing human hearts. Circ Res. 1990;66:883-890.

5. Batenburg WW, Danser AH. (Pro)renin and its receptors: pathophysiological implications. Clin Sci (Lond). 2012;123:121-133. doi: 10.1042/ CS20120042.

6. Batenburg WW, Lu X, Leijten F, Maschke U, Müller DN, Danser AH. Renin- and prorenin-induced effects in rat vascular smooth muscle cells overexpressing the human (pro)renin receptor: does (pro)renin-(pro)renin receptor interaction actually occur? Hypertension. 2011;58:1111-1119. doi: 10.1161/HYPERTENSIONAHA.111.180737.

7. Kinouchi K, Ichihara A, Sano M, Sun-Wada GH, Wada Y, Kurauchi-Mito A, Bokuda K, Narita T, Oshima Y, Sakoda M, Tamai Y, Sato H, Fukuda $\mathrm{K}$, Itoh $\mathrm{H}$. The (pro)renin receptor/ATP6AP2 is essential for vacuolar
H+-ATPase assembly in murine cardiomyocytes. Circ Res. 2010;107:3034. doi: 10.1161/CIRCRESAHA.110.224667.

8. Alexiou T, Boon WM, Denton DA, Nicolantonio RD, Walker LL, McKinley MJ, Campbell DJ. Angiotensinogen and angiotensin-converting enzyme gene copy number and angiotensin and bradykinin peptide levels in mice. J Hypertens. 2005;23:945-954.

9. Danser AH, van Kats JP, Admiraal PJ, Derkx FH, Lamers JM, Verdouw PD, Saxena PR, Schalekamp MA. Cardiac renin and angiotensins. Uptake from plasma versus in situ synthesis. Hypertension. 1994;24:37-48.

10. van Esch JH, Gembardt F, Sterner-Kock A, Heringer-Walther S, Le TH, Lassner D, Stijnen T, Coffman TM, Schultheiss HP, Danser AH, Walther T. Cardiac phenotype and angiotensin II levels in AT1a, AT1b, and AT2 receptor single, double, and triple knockouts. Cardiovasc Res. 2010;86:401409. doi: $10.1093 / \mathrm{cvr} / \mathrm{cvq} 004$.

11. Matsusaka T, Niimura F, Shimizu A, Pastan I, Saito A, Kobori H, Nishiyama A, Ichikawa I. Liver angiotensinogen is the primary source of renal angiotensin II. J Am Soc Nephrol. 2012;23:1181-1189. doi: 10.1681/ ASN.2011121159.

12. de Lannoy LM, Danser AH, van Kats JP, Schoemaker RG, Saxena PR, Schalekamp MA. Renin-angiotensin system components in the interstitial fluid of the isolated perfused rat heart. Local production of angiotensin I. Hypertension. 1997;29:1240-1251.

13. Henrion D, Benessiano J, Lévy BI. In vitro modulation of a resistance artery diameter by the tissue renin-angiotensin system of a large donor artery. Circ Res. 1997;80:189-195.

14. Yiannikouris F, Gupte M, Putnam K, Thatcher S, Charnigo R, Rateri DL, Daugherty A, Cassis LA. Adipocyte deficiency of angiotensinogen prevents obesity-induced hypertension in male mice. Hypertension. 2012;60:1524-1530. doi: 10.1161/HYPERTENSIONAHA.112.192690.

15. Gomez-Sanchez EP, Ahmad N, Romero DG, Gomez-Sanchez CE. Origin of aldosterone in the rat heart. Endocrinology. 2004;145:4796-4802. doi: 10.1210/en.2004-0295.

16. Chai W, Garrelds IM, de Vries R, Danser AH. Cardioprotective effects of eplerenone in the rat heart: interaction with locally synthesized or bloodderived aldosterone? Hypertension. 2006;47:665-670. doi: 10.1161/01. HYP.0000205831.39339.a5.

17. van der Lubbe N, Lim CH, Fenton RA, Meima ME, Danser AH, Zietse R, Hoorn EJ. Angiotensin II induces phosphorylation of the thiazide-sensitive sodium chloride cotransporter independent of aldosterone. Kidney Int. 2011;79:66-76. doi: 10.1038/ki.2010.290.

18. van Kats JP, Danser AH, van Meegen JR, Sassen LM, Verdouw PD, Schalekamp MA. Angiotensin production by the heart: a quantitative study in pigs with the use of radiolabeled angiotensin infusions. Circulation. 1998;98:73-81.

19. van Kats JP, Schalekamp MA, Verdouw PD, Duncker DJ, Danser AH. Intrarenal angiotensin II: interstitial and cellular levels and site of production. Kidney Int. 2001;60:2311-2317. doi: 10.1046/j.1523-1755.2001.00049.x.

20. van Kats JP, de Lannoy LM, Danser AH, van Meegen JR, Verdouw PD, Schalekamp MA. Angiotensin II type 1 (AT1) receptor-mediated accumulation of angiotensin II in tissues and its intracellular half-life in vivo. Hypertension. 1997;30:42-49.

21. Moltzer E, Verkuil AV, van Veghel R, Danser AH, van Esch JH. Effects of angiotensin metabolites in the coronary vascular bed of the spontaneously hypertensive rat: loss of angiotensin II type 2 receptor-mediated vasodilation. Hypertension. 2010;55:516-522. doi: 10.1161/ HYPERTENSIONAHA.109.145037.

22. You D, Loufrani L, Baron C, Levy BI, Widdop RE, Henrion D. High blood pressure reduction reverses angiotensin II type 2 receptormediated vasoconstriction into vasodilation in spontaneously hypertensive rats. Circulation. 2005;111:1006-1011. doi: 10.1161/01. CIR.0000156503.62815.48.

23. Busche S, Gallinat S, Bohle RM, Reinecke A, Seebeck J, Franke F, Fink L, Zhu M, Sumners C, Unger T. Expression of angiotensin AT(1) and $\mathrm{AT}(2)$ receptors in adult rat cardiomyocytes after myocardial infarction. A single-cell reverse transcriptase-polymerase chain reaction study. Am J Pathol. 2000;157:605-611. doi: 10.1016/S0002-9440(10)64571-3.

24. Ichihara S, Senbonmatsu T, Price E Jr, Ichiki T, Gaffney FA, Inagami T. Angiotensin II type 2 receptor is essential for left ventricular hypertrophy and cardiac fibrosis in chronic angiotensin II-induced hypertension. Circulation. 2001;104:346-351.

25. Xu J, Sun Y, Carretero OA, Zhu L, Harding P, Shesely EG, Dai X, Rhaleb NE, Peterson E, Yang XP. Effects of cardiac overexpression of the angiotensin II type 2 receptor on remodeling and dysfunction in mice postmyocardial infarction. Hypertension. 2014;63:1251-1259. doi: 10.1161/ HYPERTENSIONAHA.114.03247. 
26. Montezano AC, Touyz RM. Reactive oxygen species, vascular Noxs, and hypertension: focus on translational and clinical research. Antioxid Redox Signal. 2014;20:164-182. doi: 10.1089/ars.2013.5302.

27. Virdis A, Neves MF, Amiri F, Touyz RM, Schiffrin EL. Role of NAD(P) $\mathrm{H}$ oxidase on vascular alterations in angiotensin II-infused mice. $J$ Hypertens. 2004;22:535-542.

28. Lu H, Rateri DL, Bruemmer D, Cassis LA, Daugherty A. Involvement of the renin-angiotensin system in abdominal and thoracic aortic aneurysms. Clin Sci (Lond). 2012;123:531-543. doi: 10.1042/CS20120097.

29. Moltzer E, Essers J, van Esch JH, Roos-Hesselink JW, Danser AH. The role of the renin-angiotensin system in thoracic aortic aneurysms: clinical implications. Pharmacol Ther. 2011;131:50-60. doi: 10.1016/j. pharmthera.2011.04.002.

30. Groenink M, den Hartog AW, Franken R, Radonic T, de Waard V, Timmermans J, Scholte AJ, van den Berg MP, Spijkerboer AM, Marquering $\mathrm{HA}$, Zwinderman AH, Mulder BJ. Losartan reduces aortic dilatation rate in adults with Marfan syndrome: a randomized controlled trial. Eur Heart J. 2013;34:3491-3500. doi: 10.1093/eurheartj/eht334.

31. Habashi JP, Doyle JJ, Holm TM, Aziz H, Schoenhoff F, Bedja D, Chen Y, Modiri AN, Judge DP, Dietz HC. Angiotensin II type 2 receptor signaling attenuates aortic aneurysm in mice through ERK antagonism. Science. 2011;332:361-365. doi: 10.1126/science.1192152.

32. Moltzer E, te Riet L, Swagemakers SM, et al. Impaired vascular contractility and aortic wall degeneration in fibulin-4 deficient mice: effect of angiotensin II type 1 (AT1) receptor blockade. PLoS One. 2011;6:e23411. doi: 10.1371/journal.pone.0023411.

33. Lacro RV, Dietz HC, Sleeper LA, et al.; Pediatric Heart Network Investigators. Atenolol versus losartan in children and young adults with Marfan's syndrome. N Engl J Med. 2014;371:2061-2071. doi: 10.1056/ NEJMoa1404731.

34. Jansen R, Batista S, Brooks AI, et al. Sex differences in the human peripheral blood transcriptome. BMC Genomics. 2014;15:33. doi: 10.1186/1471-2164-15-33.

35. Orshal JM, Khalil RA. Gender, sex hormones, and vascular tone. Am J Physiol Regul Integr Comp Physiol. 2004;286:R233-R249. doi: 10.1152/ ajpregu.00338.2003.

36. Sampson AK, Jennings GL, Chin-Dusting JP. Y are males so difficult to understand?: a case where "X" does not mark the spot. Hypertension. 2012;59:525-531. doi: 10.1161/HYPERTENSIONAHA.111.187880.

37. Schunkert H, Danser AH, Hense HW, Derkx FH, Kürzinger S, Riegger GA. Effects of estrogen replacement therapy on the renin-angiotensin system in postmenopausal women. Circulation. 1997;95:39-45.

38. Hilliard LM, Sampson AK, Brown RD, Denton KM. The "his and hers" of the renin-angiotensin system. Curr Hypertens Rep. 2013;15:71-79. doi: 10.1007/s11906-012-0319-y.

39. Sampson AK, Moritz KM, Jones ES, Flower RL, Widdop RE, Denton KM. Enhanced angiotensin II type 2 receptor mechanisms mediate decreases in arterial pressure attributable to chronic low-dose angiotensin II in female rats. Hypertension. 2008;52:666-671. doi: 10.1161/ HYPERTENSIONAHA.108.114058.

40. Xue B, Pamidimukkala J, Hay M. Sex differences in the development of angiotensin II-induced hypertension in conscious mice. Am J Physiol Heart Circ Physiol. 2005;288:H2177-H2184. doi: 10.1152/ajpheart.00969.2004.

41. Danser AH, Derkx FH, Schalekamp MA, Hense HW, Riegger GA, Schunkert H. Determinants of interindividual variation of renin and prorenin concentrations: evidence for a sexual dimorphism of (pro)renin levels in humans. J Hypertens. 1998;16:853-862.

42. Bellott DW, Hughes JF, Skaletsky H, et al. Mammalian Y chromosomes retain widely expressed dosage-sensitive regulators. Nature. 2014;508:494499. doi: 10.1038/nature 13206 .

43. Ely DL, Turner ME. Hypertension in the spontaneously hypertensive rat is linked to the Y chromosome. Hypertension. 1990;16:277-281.

44. Arnold AP, Chen X. What does the "four core genotypes" mouse model tell us about sex differences in the brain and other tissues? Front Neuroendocrinol. 2009;30:1-9. doi: 10.1016/j.yfrne.2008.11.001.

45. Ji H, Zheng W, Wu X, Liu J, Ecelbarger CM, Watkins R, Arnold AP, Sandberg K. Sex chromosome effects unmasked in angiotensin IIinduced hypertension. Hypertension. 2010;55:1275-1282. doi: 10.1161/ HYPERTENSIONAHA.109.144949.

46. Staessen JA, Ginocchio G, Thijs L, Fagard R. Conventional and ambulatory blood pressure and menopause in a prospective population study. $J$ Hum Hypertens. 1997;11:507-514.

47. Carrel L, Willard HF. X-inactivation profile reveals extensive variability in X-linked gene expression in females. Nature. 2005;434:400-404. doi: 10.1038 /nature 03479 .
48. Xu J, Taya S, Kaibuchi K, Arnold AP. Sexually dimorphic expression of Usp9x is related to sex chromosome complement in adult mouse brain. Eur J Neurosci. 2005;21:3017-3022. doi: 10.1111/j.1460-9568.2005.04134.x.

49. Zhang Y, Castillo-Morales A, Jiang M, Zhu Y, Hu L, Urrutia AO, Kong X, Hurst LD. Genes that escape X-inactivation in humans have high intraspecific variability in expression, are associated with mental impairment but are not slow evolving. Mol Biol Evol. 2013;30:2588-2601. doi: 10.1093/ molbev/mst148.

50. Patrat C, Okamoto I, Diabangouaya P, Vialon V, Le Baccon P, Chow J, Heard E. Dynamic changes in paternal X-chromosome activity during imprinted X-chromosome inactivation in mice. Proc Natl Acad Sci U S A. 2009;106:5198-5203. doi: 10.1073/pnas.0810683106.

51. van der Schouw YT, van der Graaf Y, Steyerberg EW, Eijkemans JC, Banga JD. Age at menopause as a risk factor for cardiovascular mortality. Lancet. 1996;347:714-718.

52. Hudson M, Rahme E, Behlouli H, Sheppard R, Pilote L. Sex differences in the effectiveness of angiotensin receptor blockers and angiotensin converting enzyme inhibitors in patients with congestive heart failurea population study. Eur J Heart Fail. 2007;9:602-609. doi: 10.1016/j. ejheart.2007.02.001.

53. Brugts JJ, Isaacs A, Boersma E, et al. Genetic determinants of treatment benefit of the angiotensin-converting enzyme-inhibitor perindopril in patients with stable coronary artery disease. Eur Heart J. 2010;31:18541864. doi: 10.1093/eurheartj/ehq169.

54. Brugts JJ, Isaacs A, de Maat MP, et al. A pharmacogenetic analysis of determinants of hypertension and blood pressure response to angiotensin-converting enzyme inhibitor therapy in patients with vascular disease and healthy individuals. J Hypertens. 2011;29:509-519. doi: 10.1097/ HJH.0b013e328341d117.

55. Harrap SB, Tzourio C, Cambien F, Poirier O, Raoux S, Chalmers J, Chapman N, Colman S, Leguennec S, MacMahon S, Neal B, Ohkubo T, Woodward M; PROGRESS Collaborative Group. The ACE gene I/D polymorphism is not associated with the blood pressure and cardiovascular benefits of ACE inhibition. Hypertension. 2003;42:297-303. doi: 10.1161/01.HYP.0000088322.85804.96.

56. Parikh NI, Gona P, Larson MG, Wang TJ, Newton-Cheh C, Levy D, Benjamin EJ, Kannel WB, Vasan RS. Plasma renin and risk of cardiovascular disease and mortality: the Framingham Heart Study. Eur Heart J. 2007;28:2644-2652. doi: 10.1093/eurheartj/ehm399.

57. Alderman MH, Ooi WL, Cohen H, Madhavan S, Sealey JE, Laragh JH. Plasma renin activity: a risk factor for myocardial infarction in hypertensive patients. Am J Hypertens. 1997;10:1-8.

58. Szymanski MK, Damman K, van Veldhuisen DJ, van Gilst WH, Hillege HL, de Boer RA. Prognostic value of renin and prorenin in heart failure patients with decreased kidney function. Am Heart J. 2011;162:487-493. doi: 10.1016/j.ahj.2011.06.001.

59. Danser AH. Renin and prorenin as biomarkers in hypertension. Curr Opin Nephrol Hypertens. 2012;21:508-514.

60. Laragh JH, Sealey JE. The plasma renin test reveals the contribution of body sodium-volume content $(\mathrm{V})$ and renin-angiotensin $(\AA$ vasoconstriction to long-term blood pressure. Am J Hypertens. 2011;24:1164-1180. doi: 10.1038/ajh.2011.171.

61. Alderman MH, Cohen HW, Sealey JE, Laragh JH. Pressor responses to antihypertensive drug types. Am J Hypertens. 2010;23:1031-1037. doi: 10.1038/ajh.2010.114.

62. Turner ST, Schwartz GL, Chapman AB, Beitelshees AL, Gums JG, Cooper-DeHoff RM, Boerwinkle E, Johnson JA, Bailey KR. Plasma renin activity predicts blood pressure responses to beta-blocker and thiazide diuretic as monotherapy and add-on therapy for hypertension. Am J Hypertens. 2010;23:1014-1022. doi: 10.1038/ajh.2010.98.

63. Tu W, Eckert GJ, Pratt JH, Danser AH. Plasma levels of prorenin and renin in Blacks and Whites; their relative abundance and associations with plasma aldosterone concentration. Am J Hypertens. 2012;25:1030-1034. doi: 10.1038/ajh.2012.83.

64. Gupta AK, Poulter NR, Dobson J, Eldridge S, Cappuccio FP, Caulfield M, Collier D, Cruickshank JK, Sever PS, Feder G; ASCOT. Ethnic differences in blood pressure response to first and second-line antihypertensive therapies in patients randomized in the ASCOT Trial. Am J Hypertens. 2010;23:1023-1030. doi: 10.1038/ajh.2010.105.

65. Weintraub HS, Duprez DA, Cushman WC, Zappe DH, Purkayastha D, Samuel R, Izzo JL Jr. Antihypertensive response to thiazide diuretic or angiotensin receptor blocker in elderly hypertensives is not influenced by pretreatment plasma renin activity. Cardiovasc Drugs Ther. 2012;26:145155. doi: 10.1007/s10557-011-6365-x. 
66. Nussberger J, Gradman AH, Schmieder RE, Lins RL, Chiang Y, Prescott MF. Plasma renin and the antihypertensive effect of the orally active renin inhibitor aliskiren in clinical hypertension. Int J Clin Pract. 2007;61:14611468. doi: 10.1111/j.1742-1241.2007.01473.x.

67. Stanton AV, Dicker P, O'Brien ET. Aliskiren monotherapy results in the greatest and the least blood pressure lowering in patients with high- and low-baseline PRA levels, respectively. Am J Hypertens. 2009;22:954-957. doi: 10.1038/ajh.2009.114.

68. Schilders JE, Wu H, Boomsma F, van den Meiracker AH, Danser AH. Renin-angiotensin system phenotyping as a guidance toward personalized medicine for ACE inhibitors: can the response to ACE inhibition be predicted on the basis of plasma renin or ACE? Cardiovasc Drugs Ther. 2014;28:335-345. doi: 10.1007/s10557-014-6537-6.

69. Danser AH, Batenburg WW, van den Meiracker AH, Danilov SM. ACE phenotyping as a first step toward personalized medicine for ACE inhibitors. Why does ACE genotyping not predict the therapeutic efficacy of ACE inhibition? Pharmacol Ther. 2007;113:607-618. doi: 10.1016/j. pharmthera.2006.12.001.

70. van Kats JP, Duncker DJ, Haitsma DB, Schuijt MP, Niebuur R, Stubenitsky R, Boomsma F, Schalekamp MA, Verdouw PD, Danser AH. Angiotensinconverting enzyme inhibition and angiotensin II type 1 receptor blockade prevent cardiac remodeling in pigs after myocardial infarction: role of tissue angiotensin II. Circulation. 2000;102:1556-1563.

71. Richer-Giudicelli C, Domergue V, Gonzalez MF, Messadi E, Azizi M, Giudicelli JF, Ménard J. Haemodynamic effects of dual blockade of the renin-angiotensin system in spontaneously hypertensive rats: influence of salt. J Hypertens. 2004;22:619-627.

72. Danser AH, van Kesteren CA, Bax WA, Tavenier M, Derkx FH, Saxena PR, Schalekamp MA. Prorenin, renin, angiotensinogen, and angiotensinconverting enzyme in normal and failing human hearts. Evidence for renin binding. Circulation. 1997;96:220-226.

73. Klotz S, Burkhoff D, Garrelds IM, Boomsma F, Danser AH. The impact of left ventricular assist device-induced left ventricular unloading on the myocardial renin-angiotensin-aldosterone system: therapeutic consequences? Eur Heart J. 2009;30:805-812. doi: 10.1093/eurheartj/ehp012.

74. Balcarek J, Sevá Pessôa B, Bryson C, Azizi M, Ménard J, Garrelds IM, McGeehan G, Reeves RA, Griffith SG, Danser AH, Gregg R. Multiple ascending dose study with the new renin inhibitor VTP-27999: nephrocentric consequences of too much renin inhibition. Hypertension. 2014;63:942-950. doi: 10.1161/HYPERTENSIONAHA.113.02893.

75. Feldman DL, Jin L, Xuan H, Contrepas A, Zhou Y, Webb RL, Mueller DN, Feldt S, Cumin F, Maniara W, Persohn E, Schuetz H, Danser AH, Nguyen G. Effects of aliskiren on blood pressure, albuminuria, and (pro) renin receptor expression in diabetic TG(mRen-2)27 rats. Hypertension. 2008;52:130-136. doi: 10.1161/HYPERTENSIONAHA.107.108845.

76. Lange S, Fraune C, Alenina N, Bader M, Danser AH, Frenay AR, van Goor H, Stahl R, Nguyen G, Schwedhelm E, Wenzel UO. Aliskiren accumulation in the kidney: no major role for binding to renin or prorenin. $J$ Hypertens. 2013;31:713-719. doi: 10.1097/HJH.0b013e32835e226b.

77. Packer M. Why do the kidneys release renin in patients with congestive heart failure? A nephrocentric view of converting-enzyme inhibition. Am J Cardiol. 1987;60:179-184.

78. Parving HH, Brenner BM, McMurray JJ, de Zeeuw D, Haffner SM, Solomon SD, Chaturvedi N, Persson F, Desai AS, Nicolaides M, Richard A, Xiang Z, Brunel P, Pfeffer MA; ALTITUDE Investigators. Cardiorenal end points in a trial of aliskiren for type 2 diabetes. $N$ Engl J Med. 2012;367:2204-2213. doi: 10.1056/NEJMoa1208799.

79. Fried LF, Emanuele N, Zhang JH, et al; VA NEPHRON-D Investigators. Combined angiotensin inhibition for the treatment of diabetic nephropathy. N Engl J Med. 2013;369:1892-1903. doi: 10.1056/NEJMoa1303154.

80. Yusuf S, Diener HC, Sacco RL, et al; PRoFESS Study Group. Telmisartan to prevent recurrent stroke and cardiovascular events. $N$ Engl J Med. 2008;359:1225-1237. doi: 10.1056/NEJMoa0804593.

81. Nussberger J, Bohlender J. Pharmacotherapy: optimal blockade of the renin-angiotensin-aldosterone system. Nat Rev Cardiol. 2013;10:183-184. doi: 10.1038/nrcardio.2013.28.

82. James PA, Oparil S, Carter BL, et al. 2014 evidence-based guideline for the management of high blood pressure in adults: report from the panel members appointed to the Eighth Joint National Committee (JNC 8). JAMA. 2014;311:507-520. doi: 10.1001/jama.2013.284427.

83. van Vark LC, Bertrand M, Akkerhuis KM, Brugts JJ, Fox K, Mourad JJ, Boersma E. Angiotensin-converting enzyme inhibitors reduce mortality in hypertension: a meta-analysis of randomized clinical trials of reninangiotensin-aldosterone system inhibitors involving 158,998 patients. Eur Heart J. 2012;33:2088-2097. doi: 10.1093/eurheartj/ehs075.
84. Cheng J, Zhang W, Zhang X, Han F, Li X, He X, Li Q, Chen J. Effect of angiotensin-converting enzyme inhibitors and angiotensin II receptor blockers on all-cause mortality, cardiovascular deaths, and cardiovascular events in patients with diabetes mellitus: a meta-analysis. JAMA Intern Med. 2014;174:773-785. doi: 10.1001/jamainternmed.2014.348.

85. Strauss MH, Hall AS. Angiotensin receptor blockers may increase risk of myocardial infarction: unraveling the ARB-MI paradox. Circulation. 2006;114:838-854. doi: 10.1161/CIRCULATIONAHA.105.594986.

86. Bangalore S, Kumar S, Wetterslev J, Messerli FH. Angiotensin receptor blockers and risk of myocardial infarction: meta-analyses and trial sequential analyses of 147020 patients from randomised trials. BMJ. 2011;342:d2234.

87. Sun L, Wang W, Xiao W, Liang H, Yang Y, Yang H. Angiotensin II induces apoptosis in intestinal epithelial cells through the AT2 receptor, GATA-6 and the Bax pathway. Biochem Biophys Res Commun. 2012;424:663-668. doi: 10.1016/j.bbrc.2012.07.003.

88. Koyama N, Nishida Y, Ishii T, Yoshida T, Furukawa Y, Narahara H. Telmisartan induces growth inhibition, DNA double-strand breaks and apoptosis in human endometrial cancer cells. PLoS One. 2014;9:e93050. doi: 10.1371/journal.pone.0093050.

89. Verdonk K, Danser AH, van Esch JH. Angiotensin II type 2 receptor agonists: where should they be applied? Expert Opin Investig Drugs. 2012;21:501-513. doi: 10.1517/13543784.2012.664131.

90. Vasan RS, Evans JC, Larson MG, Wilson PW, Meigs JB, Rifai N, Benjamin EJ, Levy D. Serum aldosterone and the incidence of hypertension in nonhypertensive persons. N Engl J Med. 2004;351:33-41. doi: 10.1056/NEJMoa033263.

91. Gros R, Ding Q, Sklar LA, Prossnitz EE, Arterburn JB, Chorazyczewski $\mathrm{J}$, Feldman RD. GPR30 expression is required for the mineralocorticoid receptor-independent rapid vascular effects of aldosterone. Hypertension. 2011;57:442-451. doi: 10.1161/HYPERTENSIONAHA.110.161653.

92. Koenig JB, Jaffe IZ. Direct role for smooth muscle cell mineralocorticoid receptors in vascular remodeling: novel mechanisms and clinical implications. Curr Hypertens Rep. 2014; 16:427. doi: 10.1007/s11906-014-0427-y.

93. Kusche-Vihrog K, Jeggle P, Oberleithner H. The role of ENaC in vascular endothelium. Pflugers Arch. 2014;466:851-859. doi: 10.1007/ s00424-013-1356-3.

94. Gennari-Moser C, Khankin EV, Escher G, Burkhard F, Frey BM, Karumanchi SA, Frey FJ, Mohaupt MG. Vascular endothelial growth factor-A and aldosterone: relevance to normal pregnancy and preeclampsia. Hypertension. 2013;61:1111-1117. doi: 10.1161/ HYPERTENSIONAHA.111.00575.

95. Zennaro MC, Rickard AJ, Boulkroun S. Genetics of mineralocorticoid excess: an update for clinicians. Eur J Endocrinol. 2013;169:R15-R25. doi: 10.1530/EJE-12-0813.

96. Zhang W, Xia X, Reisenauer MR, Rieg T, Lang F, Kuhl D, Vallon V, Kone BC. Aldosterone-induced Sgk1 relieves Dot1a-Af9-mediated transcriptional repression of epithelial $\mathrm{Na}+$ channel alpha. J Clin Invest. 2007;117:773-783. doi: 10.1172/JCI29850.

97. McCurley A, Pires PW, Bender SB, Aronovitz M, Zhao MJ, Metzger D, Chambon P, Hill MA, Dorrance AM, Mendelsohn ME, Jaffe IZ. Direct regulation of blood pressure by smooth muscle cell mineralocorticoid receptors. Nat Med. 2012;18:1429-1433. doi: 10.1038/nm.2891.

98. Galmiche G, Pizard A, Gueret A, El Moghrabi S, Ouvrard-Pascaud A, Berger S, Challande P, Jaffe IZ, Labat C, Lacolley P, Jaisser F. Smooth muscle cell mineralocorticoid receptors are mandatory for aldosteronesalt to induce vascular stiffness. Hypertension. 2014;63:520-526. doi: 10.1161/HYPERTENSIONAHA.113.01967.

99. Montezano AC, Callera GE, Yogi A, He Y, Tostes RC, He G, Schiffrin EL, Touyz RM. Aldosterone and angiotensin II synergistically stimulate migration in vascular smooth muscle cells through c-Src-regulated redox-sensitive RhoA pathways. Arterioscler Thromb Vasc Biol. 2008;28:1511-1518. doi: 10.1161/ATVBAHA.108.168021.

100. Pruthi D, McCurley A, Aronovitz M, Galayda C, Karumanchi SA, Jaffe IZ. Aldosterone promotes vascular remodeling by direct effects on smooth muscle cell mineralocorticoid receptors. Arterioscler Thromb Vasc Biol. 2014;34:355-364. doi: 10.1161/ATVBAHA.113.302854.

101. Stowasser M, Sharman J, Leano R, Gordon RD, Ward G, Cowley D, Marwick TH. Evidence for abnormal left ventricular structure and function in normotensive individuals with familial hyperaldosteronism type I. $J$ Clin Endocrinol Metab. 2005;90:5070-5076. doi: 10.1210/jc.2005-0681.

102. Kusche-Vihrog K, Sobczak K, Bangel N, Wilhelmi M, NechyporukZloy V, Schwab A, Schillers H, Oberleithner H. Aldosterone and amiloride alter ENaC abundance in vascular endothelium. Pflugers Arch. 2008;455:849-857. doi: 10.1007/s00424-007-0341-0. 
103. Oberleithner H, Riethmüller C, Schillers H, MacGregor GA, de Wardener HE, Hausberg M. Plasma sodium stiffens vascular endothelium and reduces nitric oxide release. Proc Natl Acad Sci U S A. 2007;104:1628116286. doi: 10.1073/pnas.0707791104.

104. Gros R, Ding Q, Liu B, Chorazyczewski J, Feldman RD. Aldosterone mediates its rapid effects in vascular endothelial cells through GPER activation. Am J Physiol Cell Physiol. 2013;304:C532-C540. doi: 10.1152/ ajpcell.00203.2012.

105. Prossnitz ER, Arterburn JB, Smith HO, Oprea TI, Sklar LA, Hathaway HJ. Estrogen signaling through the transmembrane G protein-coupled receptor GPR30. Аnпu Rev Physiol. 2008;70:165-190. doi: 10.1146/annurev.physiol.70.113006.100518.

106. Batenburg WW, Jansen PM, van den Bogaerdt AJ, Danser AH. Angiotensin II-aldosterone interaction in human coronary microarteries involves GPR30, EGFR, and endothelial NO synthase. Cardiovasc Res. 2012;94:136-143. doi: 10.1093/cvr/cvs016.

107. Funder JW, Carey RM, Fardella C, Gomez-Sanchez CE, Mantero F, Stowasser M, Young WF Jr, Montori VM; Endocrine Society. Case detection, diagnosis, and treatment of patients with primary aldosteronism: an endocrine society clinical practice guideline. J Clin Endocrinol Metab. 2008;93:3266-3281. doi: 10.1210/jc.2008-0104.

108. Jansen PM, Boomsma F, van den Meiracker AH; Dutch ARRAT Investigators. Aldosterone-to-renin ratio as a screening test for primary aldosteronism-the Dutch ARRAT Study. Neth J Med. 2008;66:220-228.

109. Campbell DJ, Nussberger J, Stowasser M, Danser AH, Morganti A, Frandsen E, Ménard J. Activity assays and immunoassays for plasma Renin and prorenin: information provided and precautions necessary for accurate measurement. Clin Chem. 2009;55:867-877. doi: 10.1373/ clinchem.2008.118000.

110. Jansen PM, van den Born BJ, Frenkel WJ, de Bruijne EL, Deinum J, Kerstens MN, Smulders YM, Woittiez AJ, Wijbenga JA, Zietse R, Danser $\mathrm{AH}$, van den Meiracker AH. Test characteristics of the aldosterone-torenin ratio as a screening test for primary aldosteronism. $J$ Hypertens. 2014;32:115-126. doi: 10.1097/HJH.0b013e3283656b54.

111. Geller DS, Zhang J, Wisgerhof MV, Shackleton C, Kashgarian M, Lifton RP. A novel form of human mendelian hypertension featuring nonglucocorticoid-remediable aldosteronism. J Clin Endocrinol Metab. 2008;93:3117-3123. doi: 10.1210/jc.2008-0594.

112. Choi M, Scholl UI, Yue P, et al. K+ channel mutations in adrenal aldosterone-producing adenomas and hereditary hypertension. Science. 2011;331:768-772. doi: 10.1126/science.1198785.

113. Scholl UI, Nelson-Williams C, Yue P, Grekin R, Wyatt RJ, Dillon MJ, Couch R, Hammer LK, Harley FL, Farhi A, Wang WH, Lifton RP. Hypertension with or without adrenal hyperplasia due to different inherited mutations in the potassium channel KCNJ5. Proc Natl Acad Sci U S A. 2012;109:2533-2538. doi: 10.1073/pnas.1121407109.

114. Beuschlein F, Boulkroun S, Osswald A, et al. Somatic mutations in ATP1A1 and ATP2B3 lead to aldosterone-producing adenomas and secondary hypertension. Nat Genet. 2013;45:440-444, 444e1. doi: 10.1038/ ng. 2550.

115. Azizan EA, Poulsen H, Tuluc P, et al. Somatic mutations in ATP1A1 and CACNA1D underlie a common subtype of adrenal hypertension. Nat Genet. 2013;45:1055-1060. doi: 10.1038/ng.2716.

116. Scholl UI, Goh G, Stölting G, et al. Somatic and germline CACNA1D calcium channel mutations in aldosterone-producing adenomas and primary aldosteronism. Nat Genet. 2013;45:1050-1054. doi: 10.1038/ ng.2695.

117. Calhoun DA. Hyperaldosteronism as a common cause of resistant hypertension. Annu Rev Med. 2013;64:233-247. doi: 10.1146/ annurev-med-042711-135929.

118. Sartori M, Calò LA, Mascagna V, Realdi A, Macchini L, Ciccariello L, De Toni R, Cattelan F, Pessina AC, Semplicini A. Aldosterone and refractory hypertension: a prospective cohort study. Am J Hypertens. 2006;19:373-9; discussion 380. doi: 10.1016/j.amjhyper.2005.06.031.

119. Jansen PM, Danser AH, Imholz BP, van den Meiracker AH. Aldosteronereceptor antagonism in hypertension. J Hypertens. 2009;27:680-691. doi: 10.1097/HJH.0b013e32832810ed.

120. de Souza F, Muxfeldt E, Fiszman R, Salles G. Efficacy of spironolactone therapy in patients with true resistant hypertension. Hypertension. 2010;55:147-152. doi: 10.1161/HYPERTENSIONAHA.109.140988.

121. Jansen PM, Frenkel WJ, van den Born BJ, de Bruijne EL, Deinum J, Kerstens MN, Arnoldus JH, Woittiez AJ, Wijbenga JA, Zietse R, Danser $\mathrm{AH}$, van den Meiracker AH. Determinants of blood pressure reduction by eplerenone in uncontrolled hypertension. J Hypertens. 2013;31:404413. doi: 10.1097/HJH.0b013e32835b71d6.
122. Raheja P, Price A, Wang Z, Arbique D, Adams-Huet B, Auchus RJ, Vongpatanasin W. Spironolactone prevents chlorthalidoneinduced sympathetic activation and insulin resistance in hypertensive patients. Hypertension. 2012;60:319-325. doi: 10.1161/ HYPERTENSIONAHA.112.194787.

123. Jansen PM, van den Meiracker AH, Danser AH. Aldosterone synthase inhibitors: pharmacological and clinical aspects. Curr Opin Investig Drugs. 2009;10:319-326.

124. Bosnyak S, Jones ES, Christopoulos A, Aguilar MI, Thomas WG, Widdop RE. Relative affinity of angiotensin peptides and novel ligands at AT1 and AT2 receptors. Clin Sci (Lond). 2011;121:297-303. doi: $10.1042 / \mathrm{CS} 20110036$.

125. van Esch JH, Oosterveer CR, Batenburg WW, van Veghel R, Danser AH. Effects of angiotensin II and its metabolites in the rat coronary vascular bed: is angiotensin III the preferred ligand of the angiotensin AT2 receptor? Eur J Pharmacol. 2008;588:286-293. doi: 10.1016/j. ejphar.2008.04.042.

126. Kemp BA, Bell JF, Rottkamp DM, Howell NL, Shao W, Navar LG, Padia SH, Carey RM. Intrarenal angiotensin III is the predominant agonist for proximal tubule angiotensin type 2 receptors. Hypertension. 2012;60:387-395. doi: 10.1161/HYPERTENSIONAHA.112.191403.

127. Padia SH, Kemp BA, Howell NL, Siragy HM, Fournie-Zaluski MC, Roques BP, Carey RM. Intrarenal aminopeptidase $\mathrm{N}$ inhibition augments natriuretic responses to angiotensin III in angiotensin type 1 receptor-blocked rats. Hypertension. 2007;49:625-630. doi: 10.1161/01. HYP.0000254833.85106.4d.

128. van Esch JH, Schuijt MP, Sayed J, Choudhry Y, Walther T, Danser AH. AT2 receptor-mediated vasodilation in the mouse heart depends on AT1A receptor activation. Br J Pharmacol. 2006;148:452-458. doi: 10.1038/ sj.bjp.0706762.

129. Sevá Pessôa B, van der Lubbe N, Verdonk K, Roks AJ, Hoorn EJ, Danser AH. Key developments in renin-angiotensin-aldosterone system inhibition. Nat Rev Nephrol. 2013;9:26-36. doi: 10.1038/nrneph.2012.249.

130. Jones ES, Del Borgo MP, Kirsch JF, Clayton D, Bosnyak S, Welungoda I, Hausler N, Unabia S, Perlmutter P, Thomas WG, Aguilar MI, Widdop RE. A single beta-amino acid substitution to angiotensin II confers AT2 receptor selectivity and vascular function. Hypertension. 2011;57:570576. doi: 10.1161/HYPERTENSIONAHA.110.164301.

131. Gross V, Obst M, Luft FC. Insights into angiotensin II receptor function through AT2 receptor knockout mice. Acta Physiol Scand. 2004;181:487-494. doi: 10.1111/j.1365-201X.2004.01322.x.

132. Tanaka M, Tsuchida S, Imai T, Fujii N, Miyazaki H, Ichiki T, Naruse M, Inagami T. Vascular response to angiotensin II is exaggerated through an upregulation of AT1 receptor in AT2 knockout mice. Biochem Biophys Res Commun. 1999;258:194-198. doi: 10.1006/bbrc.1999.0500.

133. Gembardt F, Heringer-Walther S, van Esch JH, Sterner-Kock A, van Veghel R, Le TH, Garrelds IM, Coffman TM, Danser AH, Schultheiss HP, Walther T. Cardiovascular phenotype of mice lacking all three subtypes of angiotensin II receptors. FASEB J. 2008;22:3068-3077. doi: 10.1096/fj.08-108316.

134. Tsutsumi Y, Matsubara H, Masaki H, et al. Angiotensin II type 2 receptor overexpression activates the vascular kinin system and causes vasodilation. J Clin Invest. 1999;104:925-935. doi: 10.1172/JCI7886.

135. Wagenaar GT, Laghmani el H, Fidder M, Sengers RM, de Visser YP, de Vries L, Rink R, Roks AJ, Folkerts G, Walther FJ. Agonists of MAS oncogene and angiotensin II type 2 receptors attenuate cardiopulmonary disease in rats with neonatal hyperoxia-induced lung injury. Am J Physiol Lung Cell Mol Physiol. 2013;305:L341-L351. doi: 10.1152/ ajplung.00360.2012.

136. Danyel LA, Schmerler P, Paulis L, Unger T, Steckelings UM. Impact of AT2-receptor stimulation on vascular biology, kidney function, and blood pressure. Integr Blood Press Control. 2013;6:153-161. doi: 10.2147/IBPC.S34425.

137. Verdonk K, Durik M, Abd-Alla N, Batenburg WW, van den Bogaerdt AJ, van Veghel R, Roks AJ, Danser AH, van Esch JH. Compound 21 induces vasorelaxation via an endothelium- and angiotensin II type 2 receptorindependent mechanism. Hypertension. 2012;60:722-729. doi: 10.1161/ HYPERTENSIONAHA.112.196022.

138. Bosnyak S, Welungoda IK, Hallberg A, Alterman M, Widdop RE, Jones ES. Stimulation of angiotensin AT2 receptors by the non-peptide agonist, Compound 21, evokes vasodepressor effects in conscious spontaneously hypertensive rats. Br J Pharmacol. 2010;159:709-716. doi: 10.1111/j.1476-5381.2009.00575.x.

139. Anand U, Facer P, Yiangou Y, Sinisi M, Fox M, McCarthy T, Bountra C, Korchev YE, Anand P. Angiotensin II type 2 receptor (AT2 R) 
localization and antagonist-mediated inhibition of capsaicin responses and neurite outgrowth in human and rat sensory neurons. Eur J Pain. 2013;17:1012-1026. doi: 10.1002/j.1532-2149.2012.00269.x.

140. Rice AS, Dworkin RH, McCarthy TD, Anand P, Bountra C, McCloud PI, Hill J, Cutter G, Kitson G, Desem N, Raff M; EMA401-003 study group. EMA401, an orally administered highly selective angiotensin II type 2 receptor antagonist, as a novel treatment for postherpetic neuralgia: a randomised, double-blind, placebo-controlled phase 2 clinical trial. Lancet. 2014;383:1637-1647. doi: 10.1016/ S0140-6736(13)62337-5.

141. Santos RA, Simoes e Silva AC, Maric C, et al. Angiotensin-(1-7) is an endogenous ligand for the $\mathrm{G}$ protein-coupled receptor Mas. Proc Natl Acad Sci U S A. 2003;100:8258-8263. doi: 10.1073/ pnas. 1432869100 .

142. Iusuf D, Henning RH, van Gilst WH, Roks AJ. Angiotensin-(1-7): pharmacological properties and pharmacotherapeutic perspectives. Eur $J$ Pharmacol. 2008;585:303-312. doi: 10.1016/j.ejphar.2008.02.090.

143. Durik M, Sevá Pessôa B, Roks AJ. The renin-angiotensin system, bone marrow and progenitor cells. Clin Sci (Lond). 2012;123:205-223. doi: $10.1042 / \mathrm{CS} 20110660$.

144. Gurley SB, Allred A, Le TH, Griffiths R, Mao L, Philip N, Haystead TA, Donoghue M, Breitbart RE, Acton SL, Rockman HA, Coffman TM. Altered blood pressure responses and normal cardiac phenotype in ACE2-null mice. J Clin Invest. 2006;116:2218-2225. doi: 10.1172/ JCI16980.

145. Haber PK, Ye M, Wysocki J, Maier C, Haque SK, Batlle D. Angiotensin-converting enzyme 2-independent action of presumed angiotensin-converting enzyme 2 activators: studies in vivo, ex vivo, and in vitro. Hypertension. 2014;63:774-782. doi: 10.1161/ HYPERTENSIONAHA.113.02856.

146. Ferreira AJ, Santos RA, Bradford CN, Mecca AP, Sumners C, Katovich MJ, Raizada MK. Therapeutic implications of the vasoprotective axis of the renin-angiotensin system in cardiovascular diseases. Hypertension. 2010;55:207-213. doi: 10.1161/HYPERTENSIONAHA.109.140145.
147. Rodgers K, Verco S, Bolton L, Dizerega G. Accelerated healing of diabetic wounds by NorLeu(3)-angiotensin (1-7). Expert Opin Investig Drugs. 2011;20:1575-1581. doi: 10.1517/13543784.2011.619976.

148. Wright JW, Tamura-Myers E, Wilson WL, Roques BP, Llorens-Cortes C, Speth RC, Harding JW. Conversion of brain angiotensin II to angiotensin III is critical for pressor response in rats. Am J Physiol Regul Integr Comp Physiol. 2003;284:R725-R733. doi: 10.1152/ajpregu.00326.2002.

149. Fournie-Zaluski MC, Fassot C, Valentin B, Djordjijevic D, ReauxLe Goazigo A, Corvol P, Roques BP, Llorens-Cortes C. Brain reninangiotensin system blockade by systemically active aminopeptidase A inhibitors: a potential treatment of salt-dependent hypertension. Proc Natl Acad Sci U S A. 2004;101:7775-7780. doi: 10.1073/ pnas.0402312101.

150. Gao J, Marc Y, Iturrioz X, Leroux V, Balavoine F, Llorens-Cortes C. A new strategy for treating hypertension by blocking the activity of the brain renin-angiotensin system with aminopeptidase A inhibitors. Clin Sci (Lond). 2014;127:135-148. doi: 10.1042/CS20130396.

151. Faure S, Javellaud J, Achard JM, Oudart N. Vasoconstrictive effect of angiotensin IV in isolated rat basilar artery independent of AT1 and AT2 receptors. J Vasc Res. 2006;43:19-26. doi: 10.1159/000089186.

152. Rowe BP, Dixon B. Angiotensin III depressor action in the conscious rabbit is blocked by losartan but not PD 123319. Hypertension. 2000;35:130-134.

153. Vanderheyden PM. From angiotensin IV binding site to AT4 receptor. $\mathrm{Mol}$ Cell Endocrinol. 2009;302:159-166. doi: 10.1016/j.mce.2008.11.015.

154. Demaegdt H, De Backer JP, Lukaszuk A, Tóth G, Szemenyei E, Tourwé D, Vauquelin G. Angiotensin IV displays only low affinity for native insulin-regulated aminopeptidase (IRAP). Fundam Clin Pharmacol. 2012;26:194-197. doi: 10.1111/j.1472-8206.2011.00948.x.

155. Le MT, Vanderheyden PM, Szaszák M, Hunyady L, Vauquelin G. Angiotensin IV is a potent agonist for constitutive active human AT1 receptors. Distinct roles of the $\mathrm{N}$-and $\mathrm{C}$-terminal residues of angiotensin II during AT1 receptor activation. J Biol Chem. 2002;277:23107-23110. doi: 10.1074/jbc.C200201200. 


\title{
Circulation Research
}

\section{Hypertension: Renin-Angiotensin-Aldosterone System Alterations}

Luuk te Riet, Joep H.M. van Esch, Anton J.M. Roks, Anton H. van den Meiracker and A.H. Jan Danser

Circ Res. 2015;116:960-975

doi: 10.1161/CIRCRESAHA.116.303587

Circulation Research is published by the American Heart Association, 7272 Greenville Avenue, Dallas, TX 75231 Copyright (C) 2015 American Heart Association, Inc. All rights reserved. Print ISSN: 0009-7330. Online ISSN: 1524-4571

The online version of this article, along with updated information and services, is located on the World Wide Web at:

http://circres.ahajournals.org/content/116/6/960

\begin{abstract}
Permissions: Requests for permissions to reproduce figures, tables, or portions of articles originally published in Circulation Research can be obtained via RightsLink, a service of the Copyright Clearance Center, not the Editorial Office. Once the online version of the published article for which permission is being requested is located, click Request Permissions in the middle column of the Web page under Services. Further information about this process is available in the Permissions and Rights Question and Answer document.
\end{abstract}

Reprints: Information about reprints can be found online at: http://www.lww.com/reprints

Subscriptions: Information about subscribing to Circulation Research is online at: http://circres.ahajournals.org//subscriptions/ 